\title{
$\mathrm{BMJ}$
}

\section{Primary total hip arthroplasty versus hemiarthroplasty for displaced intracapsular hip fractures in older patients: systematic review}

\author{
Colin Hopley, strategic health outcomes manager, ${ }^{1}$ Dirk Stengel, senior clinical epidemiologist, ${ }^{2,3}$ Axel \\ Ekkernkamp, professor, ${ }^{2,3}$ Michael Wich, professor ${ }^{2,4}$
}

${ }^{1}$ DePuy International, Leeds LS11 $8 \mathrm{DT}$

${ }^{2}$ Department of Trauma and Orthopaedic Surgery, Unfallkrankenhaus Berlin, Berlin, Germany

${ }^{3}$ Department of Trauma and Orthopaedic Surgery, Ernst Moritz Arndt University Hospital, Greifswald, Germany

${ }^{4}$ Alice Salomon University of Applied Sciences, Berlin, Germany Correspondence to: $\mathrm{C}$ Hopley chopley@its.jnj.com

Cite this as: $B M J$ 2010;340:C2332 doi:10.1136/bmj.c2332

\section{ABSTRACT}

Objective To determine whether total hip arthroplasty is associated with lower reoperation rates, mortality, and complications, and better function and quality of life than hemiarthroplasty for displaced fractures of the femoral neck in older patients.

Design Systematic review and meta-analysis of randomised trials, quasirandomised trials, and cohort studies.

Data sources Medline, Embase, Cochrane register of controlled trials, publishers' databases, and manual search of bibliographies.

Study selection Randomised controlled trials, quasirandomised trials, and cohort studies (retrospective and prospective) comparing hemiarthroplasty with total hip arthroplasty for treating displaced femoral neck fractures in patients aged more than 60 years.

Data extraction Relative risks, risk differences, and mean differences from each trial, aggregated using random effects models. Analyses were stratified for experimental and non-experimental designs, and two way sensitivity analyses and tests for interaction were done to assess the influence of various criteria of methodological quality on pooled estimates.

Data synthesis 3821 references were identified. Of the 202 full papers inspected, 15 were included (four randomised controlled trials, three quasirandomised trials, and eight retrospective cohort studies, totalling 1890 patients). Meta-analysis of 14 studies showed a lower risk of reoperation after total hip arthroplasty compared with hemiarthroplasty (relative risk 0.57, 95\% confidence interval 0.34 to 0.96 , risk difference $4.4 \%$, $95 \%$ confidence interval $0.2 \%$ to $8.5 \%$ ), although this effect was mainly driven by investigations without concealed treatment allocation. Total hip arthroplasty consistently showed better ratings in the Harris hip score (three studies, 246 patients, weighted mean difference $5.4,95 \%$ confidence interval 2.7 to 8.2 ) after follow-up periods of 12 to 48 months. The standardised mean difference of different scores from five studies was 0.42 (95\% confidence interval 0.24 to 0.61 ), indicating a medium functional advantage of total hip arthroplasty over hemiarthroplasty. Total hip arthroplasty was associated with a slightly higher risk of dislocation (relative risk $1.48,95 \%$ confidence interval 0.89 to 2.46 ) and general complications (1.14, 0.87 to 1.48$)$.

Conclusion Single stage total hip arthroplasty may lead to lower reoperation rates and better functional outcomes compared with hemiarthroplasty in older patients with displaced femoral neck fractures. However, heterogeneity across the available trials and distinct subgroup effects preclude definitive statements and require further research in this area.

\section{INTRODUCTION}

Hip fractures in older patients are associated with impaired mobility, excess morbidity and mortality, and loss of independence. With the reversing ageing pyramid and the high prevalence of osteoporosis, hip fractures remain a public health concern. Incidence estimates vary considerably among industrial countries. ${ }^{1-9}$ Models aimed at projecting the contribution of hip fractures to the future global burden of disease produced inconclusive results, ${ }^{10}$ and depended on assumptions about the effectiveness of multifaceted interventions for preventing falls and managing osteoporosis. ${ }^{11-20}$

Typical predilection sites for fractures of the proximal femur are the femoral neck and the intertrochanteric and subtrochanteric regions. Displaced, unstable fractures of the femoral neck generally represent an indication for early surgical intervention. Established treatment options include internal fixation with cannulated or sliding hip screws, hemiarthroplasty, or total hip replacement. Well recognised goals of surgical treatment are immediate pain relief, rapid mobilisation and ambulation, accelerated rehabilitation, and maintenance of independent living. In addition to these prerequisites, the ideal implant must be associated with a low risk of surgical complications and subsequent revision. At best, patients should not be hampered by the treated hip during their remaining lifetime.

Evidence is now compelling from randomised controlled trials that, in displaced femoral neck fractures, primary arthroplasty outperforms internal fixation for complication and revision rates, function, and health 
Table 1|Summary of key criteria of individual investigations

\begin{tabular}{|c|c|c|c|c|c|c|}
\hline Study & $\begin{array}{l}\text { Recruitment } \\
\text { period }\end{array}$ & Indication & $\begin{array}{l}\text { Mean duration } \\
\text { of follow-up } \\
\text { (months) }\end{array}$ & Treatment assignment & $\begin{array}{l}\text { No of validity } \\
\text { criteria met } \\
\text { (out of } 12 \text { ) }\end{array}$ & $\begin{array}{l}\text { Outcome measures recorded } \\
\text { and analysed }\end{array}$ \\
\hline Baker $2006^{48}$ & NS & $\begin{array}{l}\text { Displaced femoral neck } \\
\text { fractures }\end{array}$ & 40 & Randomised, sealed envelopes & 8 & $\begin{array}{l}\text { Reoperations, dislocations, infections, } \\
\text { general complications, mortality, function } \\
\text { (Oxford hip score), quality of life (SF-36) }\end{array}$ \\
\hline Blomfeldt $2007^{49}$ & NS & $\begin{array}{l}\text { Displaced femoral neck } \\
\text { fractures }\end{array}$ & 12 & Randomised, sealed envelopes & 9 & $\begin{array}{l}\text { Reoperations, dislocations, infections, } \\
\text { general complications, mortality, quality of } \\
\text { life (EQ-5D) }\end{array}$ \\
\hline Dorr $1986^{50}$ & $1980-2$ & $\begin{array}{l}\text { Displaced femoral neck } \\
\text { fractures Garden III/IV }\end{array}$ & 24 & Odd and even hospital number & 9 & $\begin{array}{l}\text { Reoperations, dislocations, infections, } \\
\text { mortality, quality of life (EQ-5D) }\end{array}$ \\
\hline Eyssel $1994^{52}$ & $1984-92$ & $\begin{array}{l}\text { Displaced femoral neck } \\
\text { fractures Garden III/IV }\end{array}$ & 1 & NS & 7 & $\begin{array}{l}\text { Reoperations, dislocations, infections, } \\
\text { general complications, mortality }\end{array}$ \\
\hline Gebhard $1992^{53}$ & $1973-86$ & $\begin{array}{l}\text { Displaced femoral neck } \\
\text { fractures }\end{array}$ & 55 & NS & 6 & $\begin{array}{l}\text { Reoperations, dislocations, infections, } \\
\text { general complications, mortality }\end{array}$ \\
\hline Healy $2004^{54}$ & $1993-6$ & $\begin{array}{l}\text { Displaced femoral neck } \\
\text { fractures Garden III/IV }\end{array}$ & 71 & NS & 5 & Reoperations, infections \\
\hline Keating $2006^{45}$ & $1996-2000$ & $\begin{array}{l}\text { Displaced femoral neck } \\
\text { fractures }\end{array}$ & 24 & $\begin{array}{l}\text { Randomised, computerised } \\
\text { telephone service }\end{array}$ & 8 & $\begin{array}{l}\text { Reoperations, dislocations, infections, } \\
\text { general complications, quality of life EQ-5D }\end{array}$ \\
\hline Levi $1996^{55}$ & $1990-3$ & $\begin{array}{l}\text { Femoral neck fractures, } \\
97 \% \text { Garden III/IV }\end{array}$ & 3 & NS & 2 & Infections, mortality \\
\hline Macaulay $2008^{4243}$ & NS & $\begin{array}{l}\text { Displaced femoral neck } \\
\text { fractures Garden III/IV }\end{array}$ & 24 & $\begin{array}{l}\text { Randomised, opaque sealed } \\
\text { envelopes }\end{array}$ & 4 & $\begin{array}{l}\text { Reoperations, dislocations, infections, } \\
\text { general complications, mortality, function } \\
\text { (Harris hip score), quality of life (SF-36) }\end{array}$ \\
\hline Mouzopoulos $2008^{51}$ & 1999-2002 & $\begin{array}{l}\text { Displaced femoral neck } \\
\text { fractures Garden III/IV }\end{array}$ & 48 & Fixed alternating sequence & 3 & $\begin{array}{l}\text { Reoperations, mortality, function (Harris hip } \\
\text { score), quality of life (SF-36) }\end{array}$ \\
\hline Narayan $2006^{56}$ & $1997-2002$ & $\begin{array}{l}\text { Displaced femoral neck } \\
\text { fractures Garden III/IV }\end{array}$ & 58 & Dependent on availability & 5 & $\begin{array}{l}\text { Reoperations, dislocations, general } \\
\text { complications, function (Oxford hip score), } \\
\text { quality of life (SF-36) }\end{array}$ \\
\hline Ravikumar $2000^{46}$ & $1984-6$ & $\begin{array}{l}\text { Displaced femoral neck } \\
\text { fractures Garden III/IV }\end{array}$ & 156 & Day of week & 1 & $\begin{array}{l}\text { Reoperations; dislocations; infections; } \\
\text { mortality; quality of life (EQ-5D) }\end{array}$ \\
\hline Schleicher $2003^{57}$ & $1991-4$ & $\begin{array}{l}\text { Displaced femoral neck } \\
\text { fractures }\end{array}$ & 98 & NS & 4 & $\begin{array}{l}\text { Reoperations, dislocations, infections, } \\
\text { general complications, mortality, function } \\
\text { (Oxford hip score), quality of life (SF-36) }\end{array}$ \\
\hline Squires $1999^{58}$ & NS & $\begin{array}{l}\text { Displaced femoral neck } \\
\text { fractures }\end{array}$ & 46 & $\begin{array}{l}\text { Different treatment policy at two } \\
\text { district general hospitals }\end{array}$ & 3 & $\begin{array}{l}\text { Reoperations, dislocations, general } \\
\text { complications, function (Melzer hip score) }\end{array}$ \\
\hline Xu $2002^{59}$ & 1987-98 & $\begin{array}{l}\text { Displaced femoral neck } \\
\text { fractures }\end{array}$ & 70 & NS & 4 & $\begin{array}{l}\text { Reoperations, dislocations, infections, } \\
\text { mortality }\end{array}$ \\
\hline
\end{tabular}

related quality of life. ${ }^{21-23}$ This is reflected in recent clinical guidelines that assigned a grade A recommendation for arthroplasty to treat these fractures in older, biologically less fit patients. ${ }^{24}$

Hemiarthroplasty is a quick and highly standardised procedure that allows for early weight bearing and recovery. However, most patients with a hip fracture have osteoarthritis, which may necessitate secondary conversion to total hip replacement, especially in active elderly people with higher physical demands. Single stage surgery with acetabular replacement seems straightforward to avoid secondary admission to hospital and operation with its possible risks and extra costs. These potential benefits, however, must be traded off against the potential harms of prolonged and more invasive surgery.

Uncertainty as to which type of endoprosthesis is the ideal choice for treatment of fractures in older patients leads to significant variation in the use of each intervention internationally. ${ }^{2526}$ Total hip replacement is three times more likely to be used to treat hip fractures in Sweden than it is in England and Wales, and twice as likely than in Canada. ${ }^{27}$
To provide greater clarity about outcomes with primary hemiarthroplasty or total hip arthroplasty for displaced intracapsular hip fractures in older patients, we

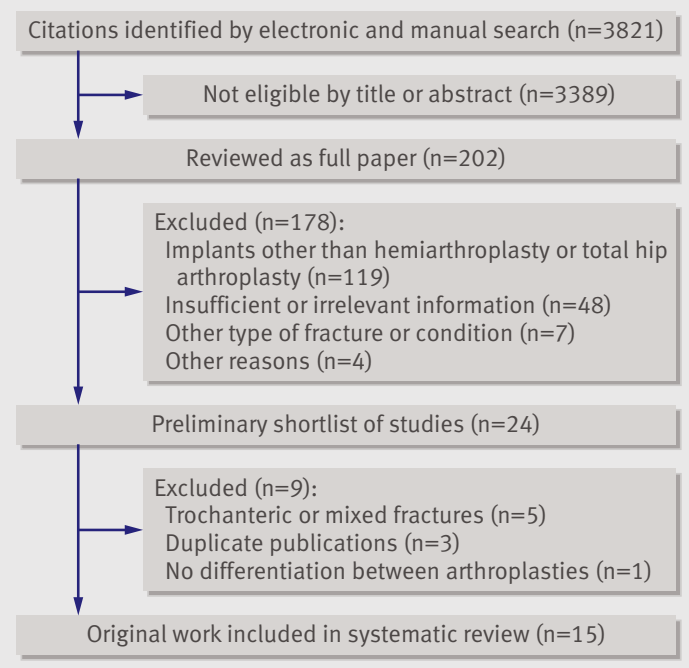

Fig 1| Review profile and study selection process 
Table 2 | Description of interventions received by each treatment group

\begin{tabular}{|c|c|c|c|c|c|c|c|}
\hline \multirow[b]{2}{*}{ Study } & \multirow[b]{2}{*}{ Design } & \multirow[b]{2}{*}{ Surgical approach } & \multicolumn{2}{|l|}{ Total hip arthroplasty } & \multicolumn{3}{|c|}{ Hemiarthroplasty } \\
\hline & & & Fixation & No & Type & Fixation & No \\
\hline Baker $2006^{48}$ & Randomised controlled trial & Transgluteal lateral & Cemented & 40 & Bipolar & Cemented & 41 \\
\hline Blomfeldt $2007^{49}$ & Randomised controlled trial & Modified Hardinge anterolateral & Cemented & 60 & Bipolar & Cemented & 60 \\
\hline Dorr $1986^{50}$ & $\begin{array}{l}\text { Lesser quality randomised } \\
\text { controlled trial }\end{array}$ & Posterior & Cemented & 39 & NS & $\begin{array}{l}\text { Cemented or } \\
\text { uncemented }\end{array}$ & 50 \\
\hline Eyssel $1994^{52}$ & Retrospective cohort & Transgluteal & Cemented & 213 & Bipolar & Cemented & 150 \\
\hline Gebhard $1992^{53}$ & Retrospective cohort & NS & Cemented & 44 & NS & Cemented or uncemented & 122 \\
\hline Healy $2004^{54}$ & Retrospective cohort & NS & Cemented & 23 & Unipolar or bipolar & Cemented & 43 \\
\hline Keating $2006^{45}$ & Randomised controlled trial & Posterior or lateral & Cemented & 69 & Bipolar & Cemented & 111 \\
\hline Levi $1996^{55}$ & Retrospective cohort & Posterior & Cemented & 98 & Unipolar & Cemented or uncemented & 123 \\
\hline Macaulay $2008^{4243}$ & Randomised controlled trial & $\begin{array}{l}\text { Posterolateral or modified } \\
\text { Hardinge anterolateral }\end{array}$ & Cemented or uncemented & 17 & Unipolar or bipolar & Cemented or uncemented & 23 \\
\hline Mouzopoulos $2008^{51}$ & $\begin{array}{l}\text { Lesser quality randomised } \\
\text { controlled trial }\end{array}$ & NS & Cemented & 43 & Bipolar & NS & 43 \\
\hline Narayan $2006^{56}$ & Retrospective cohort & NS & Cemented or uncemented & 29 & Bipolar & Cemented or uncemented & 32 \\
\hline Ravikumar $2000^{46}$ & $\begin{array}{l}\text { Lesser quality randomised } \\
\text { controlled trial }\end{array}$ & Posterolateral & Cemented & 91 & Unipolar & Uncemented & 89 \\
\hline Schleicher $2003^{57}$ & Retrospective cohort & NS & Hybrid & 54 & Bipolar & NS & 52 \\
\hline Squires $1999^{58}$ & Retrospective cohort & $\begin{array}{l}\text { Posterolateral or modified } \\
\text { Hardinge anterolateral }\end{array}$ & Cemented or uncemented & 32 & Unipolar or bipolar & Cemented or uncemented & 43 \\
\hline Xu $2002^{59}$ & Retrospective cohort & Posterior & Cemented & 32 & Unipolar or bipolar & Cemented & 24 \\
\hline
\end{tabular}

NS=not specified.

\section{No of events/ No in group \\ Treatment Control}

\section{Retrospective cohort studies}

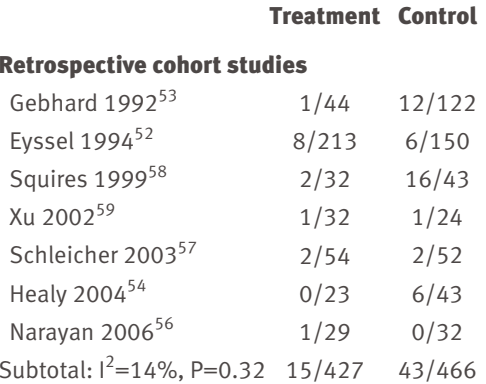

\section{Quasirandomised trials}

Dorr $1986^{50}$

Ravikumar $2000^{46}$

Mouzopoulos $2008^{51}$

Subtotal: $\left.\right|^{2}=0 \%, P=0.65$

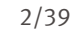

$6 / 91$

$1 / 43$

$9 / 173$

\section{Randomised trials}

Baker $2006^{48}$

Keating $2006^{45}$

Blomfeldt $2007^{49}$

Macaulay $2008^{42} 43$

$1 / 40$

$6 / 69$

$4 / 60$

$1 / 17$

Subtotal: $\left.\right|^{2}=30 \%, P=0.24 \quad 12 / 186$

Overall: $\left.\right|^{2}=27 \%, P=0.16$

$36 / 786$

$87 / 883$

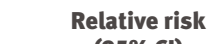
(95\% CI)

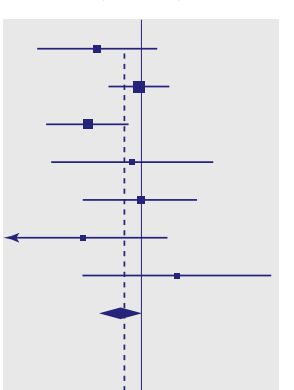

$4 / 50$

$22 / 89$

$3 / 43$

$29 / 182$
Weight

(\%)

Relative risk

5.420 .23 (0.03 to 1.73 )

13.380 .94 (0.33 to 2.65 )

$9.34 \quad 0.17$ (0.04 to 0.68$)$

$3.240 .75(0.05$ to 11.39$)$

$5.82 \quad 0.96$ (0.14 to 6.59)

3.010 .14 (0.01 to 2.40 )

2.473 .30 (0.14 to 77.95$)$

42.680 .51 (0.24 to 1.06 )

$7.41 \quad 0.64$ (0.12 to 3.32)

16.150 .27 (0.11 to 0.63 )

4.590 .33 (0.04 to 3.08)

28.150 .32 (0.16 to 0.66 )

$5.16 \quad 0.17(0.02$ to 1.36$)$

12.671 .61 (0.54 to 4.79$)$

8.841 .33 (0.31 to 5.70$)$

$2.504 .00(0.17$ to 92.57$)$

29.171 .09 ( 0.40 to 2.99 )

$100.00 \quad 0.57$ (0.34 to 0.96$)$ carried out a systematic literature review and metaanalysis of all clinical studies that aimed for a head to head comparison of either implant. We investigated complication rates and mortality and determined whether similar differences in these events, if any, could be found in randomised trials and the wider body of non-experimental studies. We also summarised patient centred outcomes such as function and health related quality of life, and investigated variables that may contribute to the observed effects.

\section{METHODS}

Two reviewers (CH and DS) independently carried out a comprehensive search (last update 27 March 2010) of Medline, Embase, the Cochrane register of controlled trials, and publishers' databases for randomised controlled trials, quasirandomised trials, and cohort studies (both retrospective and prospective) that compared hemiarthroplasty with total hip arthroplasty for treating displaced femoral neck fractures in patients aged more than 60 years. We excluded registry data and case series - that is, studies that investigated either total hip arthroplasty or hemiarthroplasty for treating hip fractures.

We used medical subject headings (or their equivalents in other databases), including the following key search and wild card terms: hip, femoral neck, intraarticular, intra-articular, fracture*, surg*, hemi*, total*, bipolar, unipolar, arthroplast*, replacement, random*. Terms were connected by the Boolean operators "AND" and "OR".

Reviewers traced the bibliographies of all retrieved trials and other relevant publications, including reviews and meta-analyses, for citations missed by the

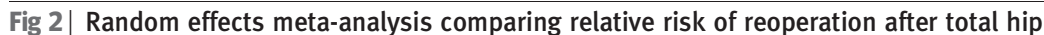
arthroplasty and hemiarthroplasty for displaced intracapsular hip fractures 
Table 3 |Characteristics of patients included in individual studies

\begin{tabular}{|c|c|c|c|c|c|c|c|c|}
\hline \multirow[b]{2}{*}{ Author } & \multicolumn{2}{|c|}{ Mean (SD) age (years) } & \multicolumn{2}{|c|}{ Male patients (\%) } & \multicolumn{2}{|c|}{$\begin{array}{l}\text { Comorbidity and preoperative risk } \\
\text { stratification }\end{array}$} & \multicolumn{2}{|c|}{ Cognitive and physical status prefracture } \\
\hline & $\begin{array}{l}\text { Total hip } \\
\text { arthroplasty }\end{array}$ & $\begin{array}{l}\text { Hemiarthro- } \\
\text { plasty }\end{array}$ & $\begin{array}{l}\text { Total hip } \\
\text { arthroplasty }\end{array}$ & $\begin{array}{l}\text { Hemiarthro- } \\
\text { plasty }\end{array}$ & $\begin{array}{l}\text { Total hip } \\
\text { arthroplasty }\end{array}$ & Hemiarthroplasty & Total hip arthroplasty & Hemiarthroplasty \\
\hline Baker $2006^{48}$ & $74(6)$ & $76(5)$ & 20 & 22 & Median ASA 2 (1-3) & Median ASA 2 (1-3) & $\begin{array}{l}\text { Mini-mental score } 10(7- \\
10)\end{array}$ & $\begin{array}{l}\text { Mini-mental score } 10 \text { (9- } \\
\text { 10) }\end{array}$ \\
\hline Blomfeldt $2007^{49}$ & $81(5)$ & $81(5)$ & 22 & 10 & Ceder A/B 88\% & Ceder A/B 83\% & $\begin{array}{l}\text { SPMSQ } 9 \text { (SD 1), } \\
\text { ADL A/B: } 97 \%\end{array}$ & $\begin{array}{l}\text { SPMSQ } 9 \text { (SD 1), } \\
\text { ADL A/B: } 98 \%\end{array}$ \\
\hline Dorr $1986^{50}$ & $69(9)$ & $69(12)$ & 41 & 30 & NS & NS & $\begin{array}{l}\text { Oriented and } \\
\text { ambulatory patients } \\
\text { only }\end{array}$ & $\begin{array}{l}\text { Oriented and ambulatory } \\
\text { patients only }\end{array}$ \\
\hline Eyssel $1994^{52}$ & $78(9)$ & $84(7)$ & 9 & 21 & Comorbidity $76 \%$ & Comorbidity $87 \%$ & Ambulatory $99 \%$ & Ambulatory $92 \%$ \\
\hline Gebhard $1992^{53}$ & 75 & 76 & NS & NS & Mean ASA 3 & Mean ASA 3 & NS & NS \\
\hline Healy $2004^{54}$ & 80 & & NS & NS & NS & NS & NS & NS \\
\hline Keating $2006^{45}$ & $75(6)$ & $75(7)$ & 25 & 17 & Comorbidity $80 \%$ & Comorbidity $70 \%$ & $\begin{array}{l}\text { Oriented and } \\
\text { ambulatory patients } \\
\text { only }\end{array}$ & $\begin{array}{l}\text { Oriented and ambulatory } \\
\text { patients only }\end{array}$ \\
\hline Levi $1996^{55}$ & 80 & 80 & 22 & 22 & NS & NS & NS & NS \\
\hline$M_{43}$ Macaulay $2008^{42}$ & $82(7)$ & $77(9)$ & 59 & 39 & $\begin{array}{c}\text { Mean No of } \\
\text { comorbidities } 4 \\
\text { (SD 2) }\end{array}$ & $\begin{array}{c}\text { Mean No of } \\
\text { comorbidities } 4 \\
\text { (SD 3) }\end{array}$ & $\begin{array}{l}\text { Oriented and } \\
\text { ambulatory patients } \\
\text { only }\end{array}$ & $\begin{array}{l}\text { Oriented and ambulatory } \\
\text { patients only }\end{array}$ \\
\hline $\begin{array}{l}\text { Mouzopoulos } \\
2008^{51}\end{array}$ & $73(5)$ & $74(4)$ & 24 & 29 & Mean ASA 2 (SD 2) & Mean ASA 2 (SD 3) & $\begin{array}{l}\text { Oriented and } \\
\text { ambulatory patients } \\
\text { only, mean SPMSQ } 8 \\
\text { (SD 3) }\end{array}$ & $\begin{array}{l}\text { Oriented and ambulatory } \\
\text { patients only, mean } \\
\text { SPMSQ } 8 \text { (SD 3) }\end{array}$ \\
\hline Narayan $2006^{56}$ & 59 & 63 & NS & NS & NS & NS & NS & NS \\
\hline Ravikumar $2000^{46}$ & 81 & 82 & 10 & 10 & No significant differe & nces in age, sex, preo & ative mobility, or comorbic & \\
\hline Schleicher $2003^{57}$ & $81(12)$ & $81(10)$ & 17 & 13 & ASA 3/4 94\% & ASA 3/4 91\% & Ambulatory 91\% & Ambulatory $100 \%$ \\
\hline Squires $1999^{58}$ & 69 & 71 & 12 & 6 & NS & NS & $\begin{array}{l}\text { Oriented and } \\
\text { ambulatory patients } \\
\text { only }\end{array}$ & $\begin{array}{l}\text { Oriented and ambulatory } \\
\text { patients only }\end{array}$ \\
\hline Xu $2002^{59}$ & $72(5)$ & $75(6)$ & 46 & 46 & NS & NS & NS & NS \\
\hline
\end{tabular}

NS=Not specified.

electronic search. See the web extra for a summary of the search strategy.

\section{Selection process}

Two reviewers $(\mathrm{CH}$ and $\mathrm{DS})$ reviewed titles and abstracts first, and independently decided whether the papers potentially contained sufficient information. If deemed eligible by either reviewer, the full paper was obtained for a detailed review. We included studies published in languages that could be read and understood by the reviewers (English, German, Dutch, Swedish, French, Spanish, and Italian). Eligible studies compared hemiarthroplasty and total hip arthroplasty in a head to head fashion and provided sufficient numerical information on at least one of the following prespecified end points: reoperation for any cause, dislocation, deep infection, one year mortality, and any general perioperative complication (including nosocomial pneumonia and urinary tract infection, as well as a thromboembolic or cardiovascular event). General complications were handled as a composite end point. We also investigated function and health related quality of life (if assessed by valid scoring systems or questionnaires).

Data abstraction and assessment of methodological quality Two reviewers ( $\mathrm{CH}$ and $\mathrm{DS}$ ) independently abstracted data in duplicate, including general information (author, publication year), type of study, fracture classification, period of patient enrolment, mean patients' age, sex distribution, prefracture comorbidity, cognitive function and mobility, average length of followup, type of prosthesis, and use of bone cement. The reviewers also extracted and entered into an electronic database event rates with nominators and denominators for different end points, as well as means and standard deviations of functional score and quality of life assessments.

Three reviewers (CH, DS, and MW) independently assessed the methodological quality of papers according to the set of items used by Parker in two previous Cochrane reviews related to this subject. ${ }^{2829}$ Quality criteria included concealment of allocation; description of entry criteria, demographic profiles, and outcomes; adherence to the intention to treat principle; blinding; handling of withdrawals; explanation of cointerventions; and a minimum follow-up of one year after surgery. The reviewers resolved disagreement by discussion.

\section{Data analysis}

We analysed binary end points (for example, reoperation and mortality) by calculating relative risks and corresponding risk differences. For differences in functional scores and quality of life instruments we calculated the weighted mean difference and the pooled 


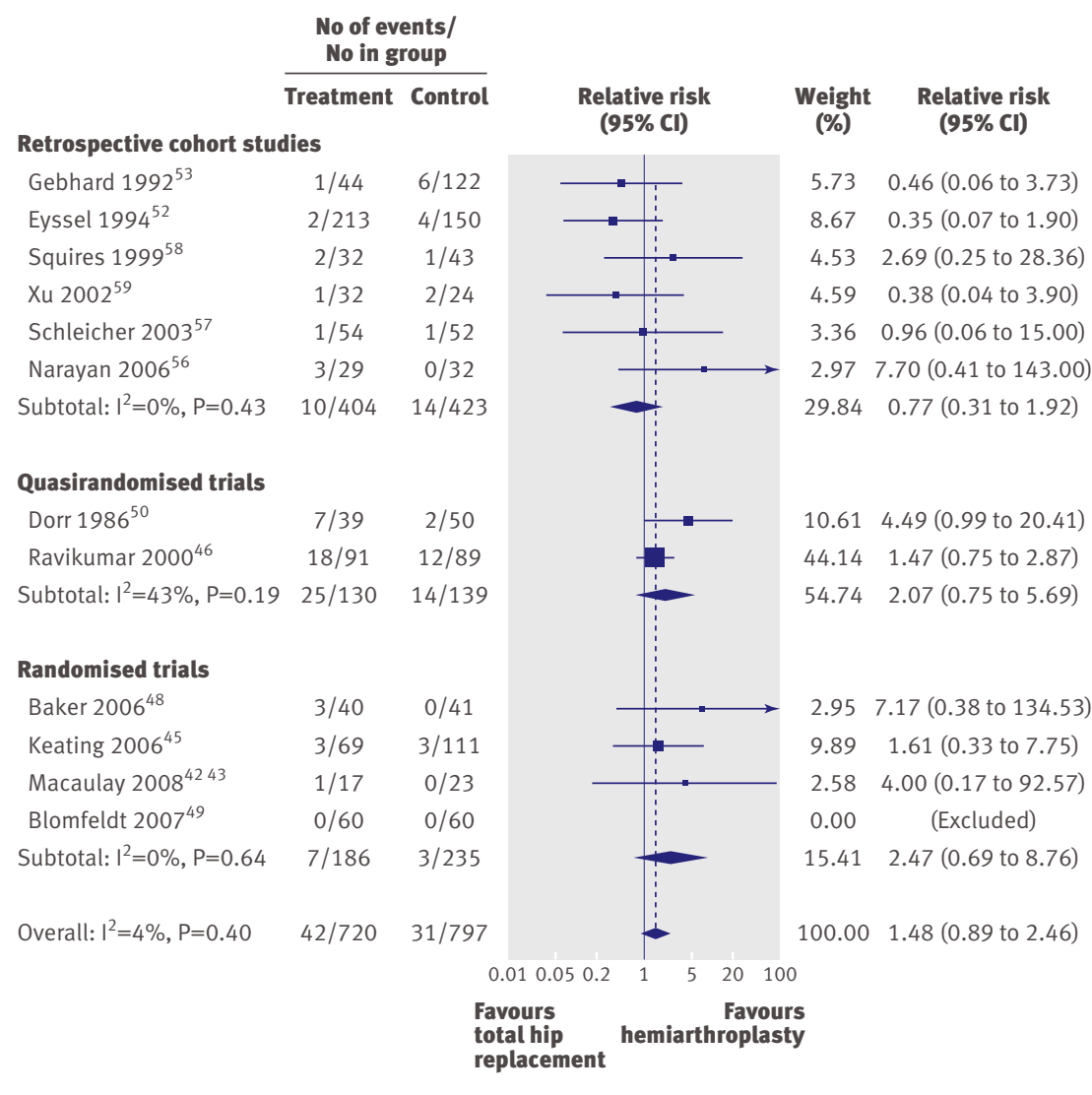

Fig 3 | Random effects meta-analysis comparing relative risk of dislocation after total hip arthroplasty and hemiarthroplasty for displaced intracapsular hip fractures

standardised mean difference. In general, higher scores indicate better function-for example, the Harris hip score, the short form 36 (SF-36) physical component score, or the European quality of life instrument 5D (EQ-5D) visual analogue scale. We reversed the polarity of inverse scores (those producing higher values with poorer function, such as the Oxford hip score ${ }^{30}$ ) by subtracting the maximum possible score from the observed score. In case authors provided ranges instead of standard deviations of means, we approximated the standard deviation by the rule of thumb range divided by 4 .

To account for variability within and between studies we used the DerSimonian-Laird random effects approach to aggregate data. ${ }^{31} \mathrm{We}$ assessed heterogeneity by using the $\mathrm{I}^{2}$ statistic, ${ }^{32}$ with values more than $50 \%$ suggesting substantial variability between studies. Publication bias was evaluated by funnel plot asymmetry and Egger's linear regression test. ${ }^{33}$ We assumed the presence of publication bias if the intercept of the regression line was significantly $(\mathrm{P}<0.1)$ away from the null.

We carried out stratified analyses for differences between the results from randomised trials and retrospective cohort studies and further differentiated between randomised trials with and without proper concealment of treatment allocation. To examine the impact of individual patient and study criteria we planned the following additional two way sensitivity analyses a priori: balanced patient profile given published information on personal details, comorbidity and ambulation (yes or no); inclusion of mobile and oriented patients only (yes or heterogeneous sample/ unclear); cementation of stems in the hemiarthroplasty group $(100 \%$ or $<100 \%$, or unclear); follow-up interval less than or more than 24 months; intention to treat analysis specified (yes or no); specification of surgeon grades in the study (yes or no); less than 5\% loss to follow-up (yes or no, or not specified); and postoperative care specified (yes or no). We compared treatment effects between independent subgroups using the test for interaction proposed by Altman and Bland, ${ }^{34}$ providing both $\mathrm{P}$ values and ratios of relative risks with $95 \%$ confidence intervals. For all calculations we used Stata 10.0 statistical software, incorporating the updated metan meta-analysis package. ${ }^{35}$

\section{RESULTS}

The electronic search strategy revealed 3821 papers, 160 of which were potentially relevant to the analysis. An additional search of the reference lists yielded 42 citations not covered by the electronic search. A shortlist of 24 papers was compiled from the set of 202 full text articles retrieved. At this stage, the reviewers omitted another nine manuscripts. Two studies, one of which was published in German and later duplicated in English, included patients with trochanteric fractures only, as did a study from Belgium. ${ }^{36-38}$

Another two studies enrolled patients with femoral neck and trochanteric fractures but did not provide sufficient information to enable separate analyses on both factors. ${ }^{3940}$ One study that compared primary joint replacement with internal fixation did not distinguish between subgroups who had undergone hemiarthroplasty and total hip arthroplasty. ${ }^{41}$

Two randomised trials were reported in duplicate. ${ }^{42-45}$ The related publications were assessed for overlapping and unique information relevant to this review. Finally, one study represented the 13 year follow-up of patients enrolled in an earlier randomised trial but had different authors. ${ }^{4647}$

For studies available in duplicate, references to the most recent publication were provided. This left 15 original reports (fig 1 ) of four randomised trials, three quasirandomised trials, and eight retrospective cohort studies, enrolling a total of 1890 patients.

\section{Study characteristics}

Tables 1-3 summarise the key characteristics of the included studies, and table 4 the criteria of methodological quality. In seven studies $(\mathrm{n}=776)$ patients were randomly allocated to hemiarthroplasty or to total hip arthroplasty. ${ }^{4345648-51}$ Concealed randomisation (sealed envelopes or a central automated telephone system) was guaranteed by four trials, all of which met most other quality criteria. ${ }^{43454849}$ In the remaining studies, patients were assigned to one of the procedures by admission numbers ${ }^{50}$ day of the week, ${ }^{46}$ or in a fixed, alternating sequence. ${ }^{51}$ Only one study stated blinded outcome assessment. ${ }^{51}$ 
Table $4 \mid$ Methodological quality of included studies

\begin{tabular}{|c|c|c|c|c|c|c|c|c|c|c|}
\hline Study & $\begin{array}{l}\text { Conceal- } \\
\text { ment of } \\
\text { allocation }\end{array}$ & $\begin{array}{c}\text { Entry criteria } \\
\text { specified }\end{array}$ & $\begin{array}{c}\text { Intention to } \\
\text { treat } \\
\text { analysis }\end{array}$ & $\begin{array}{l}\text { Intervention } \\
\text { groups } \\
\text { characterised }\end{array}$ & $\begin{array}{l}\text { Surgeon } \\
\text { grade } \\
\text { specified }\end{array}$ & $\begin{array}{c}\text { Postopera- } \\
\text { tive care }\end{array}$ & $\begin{array}{c}\text { Outcome } \\
\text { measures } \\
\text { defined }\end{array}$ & $\begin{array}{c}\text { Outcome } \\
\text { assessor } \\
\text { blinded }\end{array}$ & $\begin{array}{c}\text { Follow-up } \\
\text { period of } \geq \\
1 \text { year }\end{array}$ & $\begin{array}{c}\text { Missing } \\
\text { information } \\
\text { on }<5 \% \text { of } \\
\text { patients }\end{array}$ \\
\hline Baker $2006^{48}$ & Yes & Yes & No & Yes & Yes & Yes & Yes & No & Yes & Yes \\
\hline Keating $2006^{45}$ & Yes & Yes & Yes & Yes & Yes & Yes & Yes & No & Yes & Yes \\
\hline Blomfeldt $2007^{49}$ & Yes & Yes & Yes & Yes & Yes & Yes & Yes & No & Yes & Yes \\
\hline Macaulay $2008^{4243}$ & Yes & Yes & Yes & Yes & Yes & No & Yes & No & Yes & No \\
\hline Dorr $1986^{50}$ & No & Yes & No & Yes & No & Yes & Yes & No & Yes & Yes \\
\hline Ravikumar $2000^{46}$ & No & Yes & No & No & Yes & Yes & Yes & No & Yes & No \\
\hline Mouzopoulos $2008^{51}$ & No & Yes & Yes & Yes & No & Yes & Yes & Yes & Yes & Yes \\
\hline Gebhard $1992^{53}$ & No & No & No & No & No & No & Yes & No & Yes & No \\
\hline Eyssel $1994^{52}$ & No & No & No & Yes & Yes & Yes & Yes & No & No & No \\
\hline Levi $1996^{55}$ & No & No & No & No & Yes & Yes & Yes & No & No & No \\
\hline Squires $1999^{58}$ & No & Yes & No & Yes & Yes & No & Yes & No & Yes & Yes \\
\hline Xu $2002^{59}$ & No & No & No & No & No & No & No & No & Yes & No \\
\hline Schleicher $2003^{57}$ & No & No & No & Yes & No & No & Yes & No & Yes & Yes \\
\hline Healy $2004^{54}$ & No & No & No & No & No & No & Yes & No & Yes & Yes \\
\hline Narayan $2006^{56}$ & No & Yes & No & No & No & Yes & Yes & No & Yes & No \\
\hline
\end{tabular}

Experimental evidence was supplemented by data from eight retrospective cohort studies $(n=1114)$ of low methodological quality. ${ }^{52-59}$ The number of fulfilled quality criteria ranged from one to seven of a maximum 12. However, two of these observational studies together included 584 patients, or one third of the entire sample of participants. ${ }^{5255}$

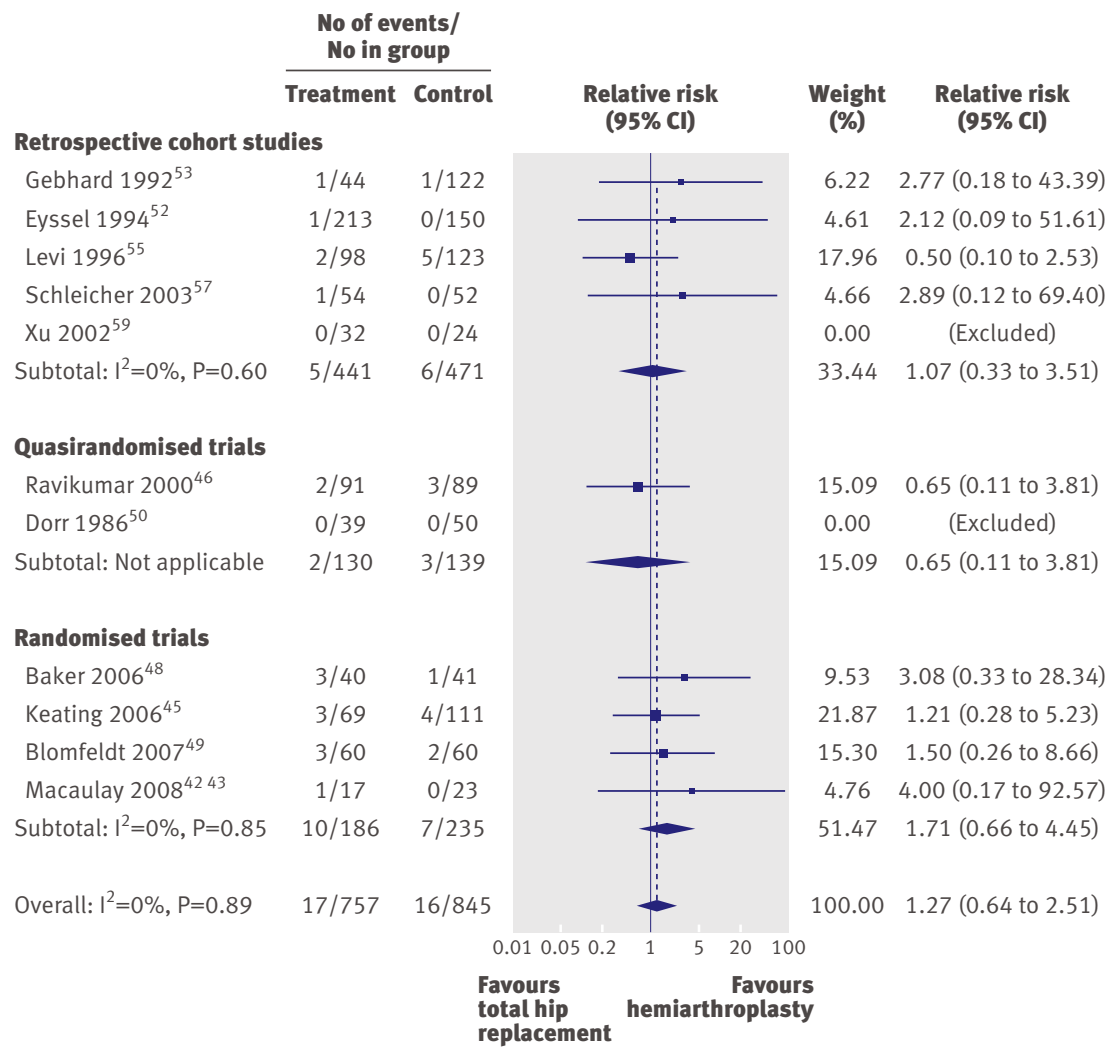

Fig 4 | Random effects meta-analysis comparing relative risk of deep infections after total hip arthroplasty and hemiarthroplasty for displaced intracapsular hip fractures
Most studies showed balanced patient baseline characteristics $(\mathrm{n}=12)$, included mobile and oriented patients only $(\mathrm{n}=10)$, attempted a minimum follow-up of more than 24 months $(\mathrm{n}=12)$, and specified postoperative care $(\mathrm{n}=9)$. Loss to follow-up was less than $5 \%$ in seven of the 15 studies, and hemiarthroplasty stems were cemented in six. Information on intention to treat analysis was provided in four studies: either all the patients were analysed according to the allocated intervention, ${ }^{4549}$ or the paper confirmed that all patients had undergone the assigned procedure. ${ }^{4351}$

According to seven studies, ${ }^{43454849525759}$ total hip replacement lengthened the duration of surgery by an average of 11 minutes (95\% confidence interval 4 to 19 minutes). Heterogeneity was significant for the reported lengths of surgery $\left(\mathrm{I}^{2}=71 \%, \mathrm{P}=0.002\right)$.

\section{Reoperation rates}

The seven randomised trials and seven of eight retrospective cohort studies, totalling 1669 patients and 123 events, provided data on reoperation rates. Overall, primary total hip arthroplasty was associated with a lower risk of subsequent reoperation compared with hemiarthroplasty (fig 2). The pooled relative risk was 0.57 (95\% confidence interval 0.34 to 0.96$)$, equalling a risk difference of $4.4 \%$ (95\% confidence interval $0.2 \%$ to $8.5 \%$ ) in favour of total hip replacement. Heterogeneity across studies was low $\left(\mathrm{I}^{2}=27 \%, \mathrm{P}=0.16\right)$. Publication bias was not evident (intercept $0.79, \mathrm{P}=0.36$ ).

Table 5 shows the influence of the study design and other prespecified variables on relative risks of reoperation. Studies with follow-up intervals of two years or longer were associated with bigger treatment effects in favour of total hip replacement (ratio of relative risks $0.44,95 \%$ confidence interval 0.15 to 1.26 , test for interaction, $\mathrm{P}=0.13)$. Treatment effects were comparable between retrospective cohort and experimental studies $(1.26,0.42$ to 3.79 , test for interaction, $\mathrm{P}=0.67)$ but seemed to be overestimated by studies with 
Table 5 |Sensitivity analysis showing influence of prespecified variables on relative risks of reoperation

\begin{tabular}{|c|c|c|c|c|c|}
\hline Variables & $\begin{array}{c}\text { No of trials/ } \\
\text { No of patients }\end{array}$ & Relative risk $(95 \% \mathrm{Cl})$ & Relative risk ratio $(95 \% \mathrm{Cl})$ & z & P value* \\
\hline \multicolumn{6}{|l|}{ Design: } \\
\hline Randomised or quasirandomised & $7 / 776$ & $0.63(0.29$ to 1.40$)$ & \multirow{2}{*}{$1.26(0.42$ to 3.79$)$} & \multirow{2}{*}{0.42} & \multirow{2}{*}{0.67} \\
\hline Retrospective cohort & $7 / 893$ & $0.50(0.23$ to 1.08$)$ & & & \\
\hline \multicolumn{6}{|l|}{ Concealment: } \\
\hline Appropriate & $4 / 421$ & 1.08 (0.39 to 3.03$)$ & \multirow{2}{*}{2.59 (0.83 to 8.07$)$} & \multirow{2}{*}{1.65} & \multirow{2}{*}{0.10} \\
\hline Unclear & $10 / 1248$ & 0.41 (0.25 to 0.68$)$ & & & \\
\hline \multicolumn{6}{|l|}{ Baseline characteristics: } \\
\hline Balanced & $12 / 1240$ & $0.55(0.30$ to 1.01$)$ & \multirow{2}{*}{0.98 (0.15 to 6.09$)$} & \multirow{2}{*}{-0.01} & \multirow{2}{*}{0.99} \\
\hline Unbalanced & $2 / 429$ & $0.56(0.10$ to 3.15$)$ & & & \\
\hline \multicolumn{6}{|l|}{ Patient sample: } \\
\hline Oriented and ambulatory & $10 / 1201$ & 0.75 (0.41 to 1.38$)$ & \multirow{2}{*}{2.80 (1.09 to 7.22$)$} & \multirow{2}{*}{2.14} & \multirow{2}{*}{0.03} \\
\hline Mixed & $4 / 468$ & $0.27(0.13$ to 0.56$)$ & & & \\
\hline \multicolumn{6}{|l|}{ Hemiarthroplasty type: } \\
\hline All cemented stems & $6 / 866$ & 0.88 (0.44 to 1.73$)$ & \multirow{2}{*}{2.35 (0.95 to 5.82$)$} & \multirow{2}{*}{1.86} & \multirow{2}{*}{0.06} \\
\hline Mixed & $8 / 803$ & 0.37 (0.20 to 0.68$)$ & & & \\
\hline \multicolumn{6}{|l|}{ Follow-up: } \\
\hline$\geq 2$ years & $12 / 1186$ & $0.47(0.26$ to 0.86$)$ & \multirow{2}{*}{$0.44(0.15$ to 1.26$)$} & \multirow{2}{*}{-1.51} & \multirow{2}{*}{0.13} \\
\hline$<2$ years & $2 / 483$ & $1.05(0.45$ to 2.45$)$ & & & \\
\hline \multicolumn{6}{|l|}{ Surgeon grade: } \\
\hline Specified & $7 / 1039$ & $0.59(0.26$ to 1.33$)$ & \multirow{2}{*}{1.13 (0.35 to 3.57$)$} & \multirow{2}{*}{0.21} & \multirow{2}{*}{0.83} \\
\hline Not specified & $7 / 630$ & $0.52(0.23$ to 1.21$)$ & & & \\
\hline \multicolumn{6}{|l|}{ Intention to treat: } \\
\hline Respected & $4 / 426$ & $1.32(0.60$ to 2.90$)$ & \multirow{2}{*}{$3.26(1.27$ to 8.33$)$} & \multirow{2}{*}{2.47} & \\
\hline Not specified & $10 / 1243$ & $0.40(0.24$ to 0.67$)$ & & & 0.01 \\
\hline Losses to follow-up & & & & & \\
\hline$<5 \%$ & $7 / 737$ & $0.60(0.28$ to 1.30$)$ & & & \\
\hline Not specified & $7 / 932$ & 0.51 (0.24 to 1.11$)$ & $1.17(0.59(0) 3.40)$ & 0.29 & 0.17 \\
\hline Postoperative care & & & & & \\
\hline Specified & $8 / 1036$ & $0.54(0.30$ to 0.96$)$ & & & \\
\hline Not specified & $6 / 633$ & $0.55(0.18$ to 1.64$)$ & $0.98(0.28$ to 3.37$)$ & -0.02 & 0.98 \\
\hline
\end{tabular}

\section{No of events/ No in group \\ Treatment Control}

\section{Retrospective cohort studies}

$\begin{array}{lcc}\text { Gebhard } 1992^{53} & 7 / 44 & 20 / 122 \\ \text { Eyssel } 1994^{52} & 81 / 213 & 77 / 150 \\ \text { Squires } 1999^{58} & 5 / 32 & 2 / 43 \\ \text { Schleicher } 2003^{57} & 33 / 54 & 29 / 52\end{array}$

Subtotal: $\left.\right|^{2}=55 \%, P=0.08 \quad 126 / 343 \quad 128 / 367$

\section{Randomised trials \\ Baker $2006^{48}$ \\ Keating $2006^{45}$ \\ Blomfeldt $2007^{49}$ \\ Macaulay $2008^{42} 43$ \\ Subtotal: $\left.\right|^{2}=0 \%, P=0.82$ \\ Overall: $\left.\right|^{2}=54 \%, P=0.03$

$\begin{array}{cc}16 / 40 & 9 / 41 \\ 14 / 69 & 16 / 111 \\ 6 / 60 & 5 / 60 \\ 15 / 17 & 16 / 23 \\ 51 / 186 & 46 / 235\end{array}$ \\ $177 / 529$}

\section{Relative risk} $(95 \% \mathrm{Cl})$

7

\section{Weight Relative risk (\%) $\quad(95 \% \mathrm{Cl})$}

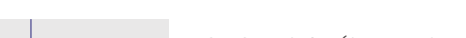

$8.18 \quad 0.97$ (0.44 to 2.14$)$

$23.620 .74(0.59$ to 0.93$)$

$2.613 .36(0.70$ to 16.22$)$

$20.251 .10(0.79$ to 1.51$)$

54.660 .96 (0.67 to 1.37$)$

9.821 .82 (0.91 to 3.64)

10.591 .41 (0.73 to 2.70 )

4.661 .20 (0.39 to 3.72 )

$20.28 \quad 1.27$ (0.92 to 1.75 )

45.341 .35 (1.04 to 1.75 )

100.001 .14 (0.87 to 1.48$)$

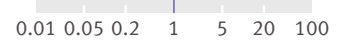
$\begin{array}{lr}\begin{array}{l}\text { Favours } \\ \text { total hip } \\ \text { replacement }\end{array} & \text { Favours } \\ & \text { hemiarthroplasty }\end{array}$ inadequate or unclear concealment of allocation (2.59, 0.83 to 8.07 , test for interaction, $\mathrm{P}=0.10$ ).

The observed benefit in reoperation rates with total hip replacement mitigated in studies that had enrolled only oriented and ambulatory patients, used only cemented stems for hemiarthroplasty, and respected the intention to treat principle (table 5).

Local and general complications

Dislocation rates were reported in 12 studies (1517 patients, 73 events). Effect sizes were homogeneous $\left(\mathrm{I}^{2}=4 \%, \mathrm{P}=0.40\right)$ and publication bias was not evident (intercept $1.43, \mathrm{P}=0.24$ ). The pooled analysis (fig 3) showed no significant difference in the risk for dislocation between total hip arthroplasty and hemiarthroplasty (relative risk 1.48, 95\% confidence interval 0.89 to 2.46 , risk difference $1.0 \%, 95 \%$ confidence interval $-1.2 \%$ to $3.2 \%$ ). A tendency was, however, noted towards a higher risk for dislocation after total hip arthroplasty among randomised and quasirandomised trials. This trend was most pronounced in studies with balanced patient baseline profiles and follow-up intervals of two or more years (table 6).
Fig 5 | Random effects meta-analysis comparing relative risk of general complications after total hip arthroplasty and hemiarthroplasty for displaced intracapsular hip fractures 


\begin{tabular}{|c|c|c|c|c|c|}
\hline Variables & $\begin{array}{l}\text { No of trials/ } \\
\text { No of patients }\end{array}$ & Relative risk $(95 \% \mathrm{Cl})$ & Relative risk ratio $(95 \% \mathrm{Cl})$ & $z$ & Pvalue* \\
\hline \multicolumn{6}{|l|}{ Design: } \\
\hline Randomised or quasirandomised & $6 / 690$ & $1.87(1.08$ to 3.25$)$ & \multirow{2}{*}{2.43 (0.83 to 7.10$)$} & \multirow{2}{*}{1.63} & \multirow{2}{*}{0.10} \\
\hline Retrospective cohort & $6 / 827$ & 0.77 (0.30 to 1.92$)$ & & & \\
\hline \multicolumn{6}{|l|}{ Concealment: } \\
\hline Appropriate & $4 / 421$ & $2.46(0.69$ to 8.76$)$ & \multirow{2}{*}{1.88 (0.44 to 7.93$)$} & \multirow{2}{*}{0.87} & \multirow{2}{*}{0.39} \\
\hline Unclear & $8 / 1096$ & 1.30 (0.66 to 2.57$)$ & & & \\
\hline \multicolumn{6}{|l|}{ Baseline characteristics: } \\
\hline Balanced & $11 / 1154$ & 1.67 (1.02 to 2.73$)$ & \multirow{2}{*}{$4.75(0.82$ to 27.57$)$} & \multirow{2}{*}{1.74} & \multirow{2}{*}{0.08} \\
\hline Unbalanced & $1 / 363$ & 0.35 (0.06 to 1.89$)$ & & & \\
\hline \multicolumn{6}{|l|}{ Patient sample: } \\
\hline Oriented and ambulatory & $9 / 1115$ & $1.99(0.93$ to 4.27$)$ & \multirow{2}{*}{1.74 (0.61 to 4.92$)$} & \multirow{2}{*}{1.05} & \multirow{2}{*}{0.29} \\
\hline Mixed & $3 / 402$ & 1.14 (0.56 to 2.32$)$ & & & \\
\hline \multicolumn{6}{|l|}{ Hemiarthroplasty type: } \\
\hline All cemented stems & $5 / 800$ & $0.91(0.27$ to 3.02$)$ & \multirow{2}{*}{0.52 (0.14 to 1.95$)$} & \multirow{2}{*}{-0.95} & \multirow{2}{*}{0.34} \\
\hline Mixed & $7 / 717$ & 1.73 (1.01 to 2.97$)$ & & & \\
\hline \multicolumn{6}{|l|}{ Follow-up: } \\
\hline$\geq 2$ years & $10 / 1034$ & 1.67 (1.02 to 2.73$)$ & \multirow{2}{*}{4.75 (0.82 to 27.48$)$} & \multirow{2}{*}{1.74} & \multirow{2}{*}{0.08} \\
\hline$<2$ years & $2 / 483$ & 0.35 (0.06 to 1.89 ) & & & \\
\hline \multicolumn{6}{|l|}{ Surgeon grade: } \\
\hline Specified & $7 / 1039$ & $1.43(0.83$ to 2.47$)$ & \multirow{2}{*}{$0.97(0.25$ to 3.63$)$} & \multirow{2}{*}{0.00} & \multirow{2}{*}{1.00} \\
\hline Not specified & $5 / 478$ & 1.47 (0.44 to 4.91$)$ & & & \\
\hline \multicolumn{6}{|l|}{ Intention to treat: } \\
\hline Respected & $3 / 340$ & $1.93(0.47$ to 7.87$)$ & \multirow{2}{*}{$1.36(0.28$ to 6.46$)$} & \multirow{2}{*}{0.39} & \\
\hline Not specified & $9 / 1177$ & $1.41(0.72$ to 2.75$)$ & & & 0.10 \\
\hline Losses to follow-up & & & & & \\
\hline$<5 \%$ & $6 / 651$ & $2.67(1.10$ to 6.49$)$ & & & \\
\hline Not specified & $6 / 866$ & 1.04 (0.47 to 2.26$)$ & $2.56(0.78$ to 8.37$)$ & 1.57 & 0.12 \\
\hline Postoperative care & & & & & \\
\hline Specified & $7 / 950$ & $1.58(0.63$ to 3.93$)$ & & & \\
\hline Not specified & $5 / 567$ & $1.36(0.51$ to 3.63$)$ & $1.15(0.30$ to 4.39$)$ & 0.21 & 0.83 \\
\hline
\end{tabular}

Deep infections occurred in 33 of 1264 patients enrolled in 11 studies. There was no heterogeneity $\left(\mathrm{I}^{2}=0 \%, \mathrm{P}=0.89\right)$ but evidence of funnel plot asymmetry (intercept 2.81, $\mathrm{P}=0.027$ ) for this end point. The pooled relative risk of infection after total hip arthroplasty compared with hemiarthroplasty was 1.27 (95\% confidence interval 0.64 to 2.51 ), translating into a risk difference of $0.4 \%$ (95\% confidence interval $-0.7 \%$ to $1.6 \%)$. Results were virtually similar among experimental, quasiexperimental, and retrospective cohort studies (fig 4). Also, no substantial interaction was noted between all investigated subgroups for this end point (table 7).

General complications were observed slightly more often after total hip arthroplasty than after hemiarthroplasty (relative risk 1.14, 95\% confidence interval 0.87 to 1.48 , risk difference $3.7 \%, 95 \%$ confidence interval $-3.7 \%$ to $11.1 \%$ ). This trend was consistently observed in randomised trials (fig 5) as well as in studies with balanced patient baseline profiles and follow-up intervals of two or more years (table 8). Results were prone to publication bias (intercept 4.09, $\mathrm{P}=0.033$ ).
One year mortality

Nine studies (1023 patients, 178 events) provided data on one year mortality. There was no evidence of heterogeneity $\left(\mathrm{I}^{2}=0 \%, \mathrm{P}=0.85\right)$ and publication bias (intercept $0.22, \mathrm{P}=0.76)$. Altogether, mortality did not differ between patients undergoing total hip arthroplasty and hemiarthroplasty (relative risk 0.92, 95\% confidence interval 0.70 to 1.21 , risk difference $1.4 \%, 95 \%$ confidence interval $-2.6 \%$ to $5.4 \%$ ). Notable benefits were observed in randomised trials (fig 6); however, the test for interaction did not reveal significant differences between subgroups (table 9).

\section{Function and health related quality of life}

The Harris hip score was used for outcome assessment in three randomised trials and in 246 patients, with follow-up intervals ranging from 12 to 48 months. ${ }^{43491}$ This score contains the subscales pain, function, deformity, and range of motion, and may achieve values from 0 to 100 points, with higher scores indicating better function. ${ }^{60}$ Total hip replacement was consistently associated with better function in all studies $\left(\mathrm{I}^{2}=4 \%\right.$, 
Table $7 \mid$ Sensitivity analysis showing influence of prespecified variables on relative risks of deep infection

\begin{tabular}{|c|c|c|c|c|c|}
\hline Variables & $\begin{array}{c}\text { No of trials/ } \\
\text { No of patients }\end{array}$ & Relative risk $(95 \% \mathrm{Cl})$ & Relative risk ratio $(95 \% \mathrm{Cl})$ & z & P value* \\
\hline \multicolumn{6}{|l|}{ Design: } \\
\hline Randomised or quasirandomised & $6 / 690$ & 1.37 (0.59 to 3.18$)$ & \multirow{2}{*}{$1.28(0.29$ to 5.47$)$} & \multirow{2}{*}{0.33} & \multirow{2}{*}{0.74} \\
\hline Retrospective cohort & $5 / 912$ & $1.07(0.32$ to 3.51$)$ & & & \\
\hline \multicolumn{6}{|l|}{ Concealment: } \\
\hline Appropriate & $4 / 421$ & $1.71(0.65$ to 4.44$)$ & \multirow{2}{*}{$1.86(0.47$ to 7.34$)$} & \multirow{2}{*}{0.89} & \multirow{2}{*}{0.38} \\
\hline Unclear & 7/1181 & 0.91 (0.34 to 2.46$)$ & & & \\
\hline \multicolumn{6}{|l|}{ Baseline characteristics: } \\
\hline Balanced & $9 / 1018$ & $1.52(0.69$ to 3.31$)$ & \multirow{2}{*}{$2.25(0.43$ to 11.63$)$} & \multirow{2}{*}{0.97} & \multirow{2}{*}{0.33} \\
\hline Unbalanced & $2 / 584$ & $0.67(0.15$ to 2.85$)$ & & & \\
\hline \multicolumn{6}{|l|}{ Patient sample: } \\
\hline Oriented and ambulatory & $7 / 979$ & $1.81(0.75$ to 4.36$)$ & \multirow{2}{*}{$2.48(0.61$ to 10.11$)$} & \multirow{2}{*}{1.27} & \multirow{2}{*}{0.20} \\
\hline Mixed & $4 / 623$ & $0.72(0.24$ to 2.17$)$ & & & \\
\hline \multicolumn{6}{|l|}{ Hemiarthroplasty type: } \\
\hline All cemented stems & $5 / 800$ & 1.61 (0.61 to 4.19) & \multirow{2}{*}{$1.64(0.41$ to 6.47$)$} & \multirow{2}{*}{0.71} & \multirow{2}{*}{0.48} \\
\hline Mixed & $6 / 802$ & $0.98(0.36$ to 2.62$)$ & & & \\
\hline \multicolumn{6}{|l|}{ Follow-up: } \\
\hline$\geq 2$ years & $8 / 898$ & $1.52(0.63$ to 3.64$)$ & \multirow{2}{*}{$1.63(0.39$ to 6.74$)$} & \multirow{2}{*}{0.69} & \multirow{2}{*}{0.49} \\
\hline$<2$ years & $3 / 704$ & $0.93(0.30$ to 2.83$)$ & & & \\
\hline \multicolumn{6}{|l|}{ Surgeon grade: } \\
\hline Specified & $7 / 1185$ & $1.14(0.55$ to 2.37$)$ & \multirow{2}{*}{0.40 (0.04 to 3.67$)$} & \multirow{2}{*}{-0.80} & \multirow{2}{*}{0.42} \\
\hline Not specified & $4 / 417$ & $2.82(0.35$ to 22.5$)$ & & & \\
\hline \multicolumn{6}{|l|}{ Intention to treat: } \\
\hline Respected & $3 / 340$ & $1.49(0.51$ to 4.31$)$ & \multirow{2}{*}{$1.33(0.33$ to 5.36$)$} & \multirow{2}{*}{0.41} & \\
\hline Not specified & $8 / 1262$ & $1.12(0.45$ to 2.75$)$ & & & 0.00 \\
\hline Losses to follow-up: & & & & & \\
\hline$<5 \%$ & $5 / 576$ & $1.65(0.63$ to 4.31$)$ & & & \\
\hline Not specified & $6 / 1026$ & $0.95(0.35$ to 2.54$)$ & $1.74(0.44(00.07)$ & 0.19 & 0.43 \\
\hline Postoperative care: & & & & & \\
\hline Specified & $7 / 1110$ & $1.02(0.43$ to 2.44$)$ & & & \\
\hline Not specified & 4/492 & $1.79(0.58$ to 5.50$)$ & $0.57(0.13$ to 2.35$)$ & -0.18 & 0.44 \\
\hline
\end{tabular}

$\mathrm{P}=0.35$ ) (fig 7), and without evidence of publication bias (intercept $-0.18, \mathrm{P}=0.95$ ). The weighted mean difference in favour of total hip replacement was $5.4(95 \%$ confidence interval 2.7 to 8.2 ).

Another trial ${ }^{45}$ had utilised the hip rating questionnaire, an instrument consisting of the four subscales arthritis, pain, walking, and daily function. Scores may range from 16 to 100 points. ${ }^{61}$ At final follow-up after 24 months, the weighted mean difference was 6.1 (95\% confidence interval 0.4 to 11.8 ) in favour of total hip replacement.

The Oxford hip score was used for functional outcome measurement in another trial. ${ }^{48}$ This score ranges from 12 to 60 points, with higher values indicating poorer function. ${ }^{62}$ After three years of follow-up, hip function after total hip arthroplasty was rated slightly better than after hemiarthroplasty, by 3.5 points ( $95 \%$ confidence interval -0.7 to 7.7 points).

The standardised mean difference from all trials was estimated at $0.42(95 \%$ confidence interval 0.24 to 0.61 ), indicating a medium functional benefit of total hip replacement. ${ }^{63}$
SF-36 physical component scores were available from two trials totalling 121 patients, ${ }^{43}{ }^{48}$ with no differences between total hip arthroplasty and hemiarthroplasty (weighted mean difference 1.9, 95\% confidence interval -2.2 to 6.0 ). Another trial had used EQ-5D utility scores, which were rated significantly better in the total hip arthroplasty group compared with the hemiarthroplasty group after two years of follow-up (mean difference $0.16,95 \%$ confidence interval 0.05 to $0.27) .{ }^{45}$

\section{DISCUSSION}

The purpose of this review was to provide additional insight into the options for treating intracapsular hip fractures, focusing on the role of total hip replacement now that there is a significant body of evidence indicating that older patients treated with arthroplasty of all types have fewer complication rates and better health outcomes than those treated with internal fixation. Total hip arthroplasty compared with hemiarthroplasty was found to be beneficial for reoperation rates and functional outcomes. It is unclear whether patients 
Table $8 \mid$ Sensitivity analysis showing influence of prespecified variables on relative risks of general complications

\begin{tabular}{|c|c|c|c|c|c|}
\hline Variables & $\begin{array}{l}\text { No of trials/ } \\
\text { No of patients }\end{array}$ & Relative risk $(95 \% \mathrm{Cl})$ & Relative risk ratio $(95 \% \mathrm{Cl})$ & z & P value* \\
\hline \multicolumn{6}{|l|}{ Design: } \\
\hline Randomised or quasirandomised & $4 / 421$ & 1.35 (1.04 to 1.75$)$ & \multirow{2}{*}{1.41 (0.91 to 2.19$)$} & \multirow{2}{*}{1.54} & \multirow{2}{*}{0.12} \\
\hline Retrospective cohort & $4 / 710$ & $0.95(0.67$ to 1.36$)$ & & & \\
\hline \multicolumn{6}{|l|}{ Concealment: } \\
\hline Appropriate & $4 / 421$ & 1.35 (1.04 to 1.75$)$ & \multirow{2}{*}{1.41 (0.91 to 2.19$)$} & \multirow{2}{*}{1.54} & \multirow{2}{*}{0.12} \\
\hline Unclear & $4 / 710$ & 0.95 (0.67 to 1.36$)$ & & & \\
\hline \multicolumn{6}{|l|}{ Baseline characteristics: } \\
\hline Balanced & $7 / 768$ & 1.24 (1.02 to 1.51$)$ & \multirow{2}{*}{1.68 (1.24 to 2.27$)$} & \multirow{2}{*}{3.37} & \multirow{2}{*}{$<0.01$} \\
\hline Unbalanced & $1 / 363$ & 0.74 (0.58 to 0.93$)$ & & & \\
\hline \multicolumn{6}{|l|}{ Patient sample: } \\
\hline Oriented and ambulatory & $7 / 965$ & $1.16(0.86$ to 1.56$)$ & \multirow{2}{*}{$1.20(0.51$ to 2.78$)$} & \multirow{2}{*}{0.43} & \multirow{2}{*}{0.67} \\
\hline Mixed & $1 / 166$ & 0.97 (0.44 to 2.13$)$ & & & \\
\hline \multicolumn{6}{|l|}{ Hemiarthroplasty type: } \\
\hline All cemented stems & $4 / 744$ & 1.14 (0.68 to 1.93$)$ & \multirow{2}{*}{$0.96(0.55$ to 1.70$)$} & \multirow[b]{2}{*}{-0.11} & \multirow{2}{*}{0.92} \\
\hline Mixed & $4 / 387$ & $1.18(0.95$ to 1.47$)$ & & & \\
\hline \multicolumn{6}{|l|}{ Follow-up: } \\
\hline$\geq 2$ years & $6 / 648$ & 1.24 (1.02 to 1.51$)$ & \multirow{2}{*}{$1.65(1.22$ to 2.23$)$} & \multirow{2}{*}{3.27} & \multirow{2}{*}{$<0.01$} \\
\hline$<2$ years & $2 / 483$ & 0.75 (0.60 to 0.94$)$ & & & \\
\hline \multicolumn{6}{|l|}{ Surgeon grade: } \\
\hline Specified & $6 / 859$ & $1.22(0.83$ to 1.80$)$ & \multirow{2}{*}{$1.13(0.69$ to 1.85$)$} & \multirow{2}{*}{0.52} & \multirow{2}{*}{0.60} \\
\hline Not specified & $2 / 272$ & 1.07 (0.79 to 1.45$)$ & & & \\
\hline \multicolumn{6}{|l|}{ Intention to treat: } \\
\hline Respected & $3 / 340$ & 1.28 (0.97 to 1.70$)$ & \multirow{2}{*}{1.18 (0.73 to 1.89$)$} & \multirow{2}{*}{0.70} & \\
\hline Not specified & $5 / 791$ & $1.08(0.74$ to 1.58$)$ & & & 0.48 \\
\hline Losses to follow-up: & & & & & \\
\hline$<5 \%$ & $5 / 562$ & $1.26(0.97$ to 1.63$)$ & & & \\
\hline Not specified & $3 / 569$ & $0.95(0.62$ to 1.48$)$ & 1.31 (0.79 to 2.18$)$ & 1.07 & 0.28 \\
\hline Postoperative care: & & & & & \\
\hline Specified & $3 / 564$ & 1.09 (0.56 to 2.11$)$ & & & \\
\hline Not specified & $5 / 567$ & $1.20(0.98$ to 1.48$)$ & 0.90 (0.45 to 1.80$)$ & -0.28 & 0.78 \\
\hline
\end{tabular}

undergoing total hip replacement may also benefit from a small survival advantage after one year. The potential advantages must be traded off against a possible higher risk of dislocation and general complications, higher invasiveness, and longer theatre times.

\section{Strengths and weaknesses of this review}

This is the first review to compile all available head to head investigations of total hip arthroplasty compared with hemiarthroplasty for femoral neck fractures. By including both experimental and non-experimental studies, the sample size and robustness of estimates was enhanced compared with previous reviews. Yet, the number of available studies was small, and with an overall sample size of fewer than 2000 patients our results do not allow for conclusive statements on the effectiveness of total hip arthroplasty and hemiarthroplasty for treating femoral neck fractures.

Some might argue about the inclusion of retrospective cohort studies because of their inherent risk of bias. However, such studies enrolled a significant number of patients and, despite methodological limitations, ignoring this source of data might have affected the external validity of our findings. The researchers were diligent about extracting as much information as possible from the available papers. We tried to control our computations for confounding, carried out various sensitivity analyses, and explored the interaction between subgroups.

There is no doubt that only randomisation creates biologically similar patient cohorts, in which unknown confounders are equally distributed, and allows for inferences on causal relations between exposure and outcome. It might be assumed that in non-randomised studies, patients with poorer prognosis were more likely to undergo the faster, less invasive procedure of hemiarthroplasty, thereby introducing selection and differential indication bias.

Although the published information on patient profiles was limited in quantity and quality, participants enrolled in the retrospective cohort studies were not entirely different from those enrolled in the randomised trials. This is not surprising, since the typical patient presenting with a femoral neck fracture to an emergency department in an industrial country (thus being a potential candidate for a clinical study) is a 
Table $9 \mid$ Sensitivity analysis showing influence of prespecified variables on relative risks of one year mortality

\begin{tabular}{|c|c|c|c|c|c|}
\hline Variables & $\begin{array}{c}\text { No of trials/No of } \\
\text { patients }\end{array}$ & Relative risk $(95 \% \mathrm{Cl})$ & Relative risk ratio $(95 \% \mathrm{Cl})$ & z & P value* \\
\hline \multicolumn{6}{|l|}{ Design: } \\
\hline Randomised or quasirandomised & $6 / 695$ & $0.8(0.56$ to 1.14$)$ & \multirow{2}{*}{$0.71(0.41$ to 1.24$)$} & \multirow{2}{*}{-1.19} & \multirow{2}{*}{0.24} \\
\hline Retrospective cohort & $3 / 328$ & $1.11(0.73$ to 1.71$)$ & & & \\
\hline \multicolumn{6}{|l|}{ Concealment: } \\
\hline Appropriate & $3 / 340$ & $0.67(0.29$ to 1.50$)$ & \multirow{2}{*}{$0.70(0.29$ to 1.65$)$} & \multirow{2}{*}{-0.81} & \multirow{2}{*}{0.42} \\
\hline Unclear & $6 / 683$ & $0.95(0.71$ to 1.27$)$ & & & \\
\hline \multicolumn{6}{|l|}{ Baseline characteristics: } \\
\hline Balanced & $9 / 1023$ & 0.91 (0.69 to 1.20$)$ & \multirow{2}{*}{-} & \multirow{2}{*}{-} & \multirow{2}{*}{-} \\
\hline Unbalanced & 0 & - & & & \\
\hline \multicolumn{6}{|l|}{ Patient sample: } \\
\hline Oriented and ambulatory & $6 / 621$ & $0.88(0.57$ to 1.37$)$ & \multirow{2}{*}{0.94 (0.53 to 1.66$)$} & \multirow{2}{*}{-0.20} & \multirow{2}{*}{0.84} \\
\hline Mixed & $3 / 402$ & $0.93(0.66$ to 1.32$)$ & & & \\
\hline \multicolumn{6}{|l|}{ Hemiarthroplasty type: } \\
\hline All cemented stems & $3 / 356$ & 0.84 (0.40 to 1.77$)$ & \multirow{2}{*}{0.90 (0.40 to 2.02$)$} & \multirow{2}{*}{-0.24} & \multirow{2}{*}{0.81} \\
\hline Mixed & $6 / 667$ & $0.93(0.69$ to 1.24$)$ & & & \\
\hline \multicolumn{6}{|l|}{ Follow-up: } \\
\hline$\geq 2$ years & $8 / 903$ & 0.90 (0.68 to 1.19$)$ & \multirow{2}{*}{0.67 (0.15 to 2.98$)$} & \multirow{2}{*}{-0.51} & \multirow{2}{*}{0.61} \\
\hline$<2$ years & $1 / 120$ & $1.33(0.31$ to 5.70$)$ & & & \\
\hline \multicolumn{6}{|l|}{ Surgeon grade: } \\
\hline Specified & $4 / 520$ & $0.79(0.51$ to 1.22$)$ & \multirow{2}{*}{0.79 (0.45 to 1.37$)$} & \multirow{2}{*}{-0.83} & \multirow{2}{*}{0.41} \\
\hline Not specified & $5 / 503$ & $1.01(0.70$ to 1.43$)$ & & & \\
\hline \multicolumn{6}{|l|}{ Intention to treat: } \\
\hline Respected & $4 / 426$ & $0.72(0.42$ to 1.23$)$ & \multirow{2}{*}{$0.72(0.38$ to 1.34$)$} & \multirow{2}{*}{-1.02} & \\
\hline Not specified & $5 / 597$ & $1(0.72$ to 1.37$)$ & & & 0.31 \\
\hline Losses to follow-up: & & & & & \\
\hline$<5 \%$ & $5 / 581$ & 0.93 (0.59 to 1.47$)$ & & & \\
\hline Not specified & $4 / 442$ & $0.90(0.64$ to 1.27$)$ & 1.03 (0.58 t0 1.82) & 0.12 & 0.90 \\
\hline Postoperative care: & & & & & \\
\hline Specified & $5 / 531$ & 0.87 (0.60 to 1.26$)$ & & & \\
\hline Not specified & 4/492 & $0.96(0.59$ to 1.54$)$ & $0.90(0.49$ to 1.65$)$ & -0.32 & 0.15 \\
\hline
\end{tabular}

woman in her mid-70s with osteoporosis, cardiovascular comorbidity, and associated drugs. The available information did not support the thesis that different treatment assignment in non-randomised studies was mainly based on preoperative risk assessment. Although we do not discount this, we suspect that in these studies surgeons' preferences, as well as disposability of teams, hardware, and theatre time slots, contributed to the decision to implant a total hip or a bipolar prosthesis. This does, however, resemble clinical reality.

We noted further interesting patterns of treatment effects that may be useful for planning future trials. Random assignment to interventions in itself had little influence on the reported reoperation rates. In fact, the observed advantage with total hip replacement disappeared with adequate concealment of allocation, which may be an important surrogate of higher methodological quality. Other features such as the recruitment of physically and mentally fit patients and routine cementation of stems in the hemiarthroplasty control group mitigated (but still did not exclude) favourable reoperation risks after total hip arthroplasty.
Upcoming trial protocols should respect these important variables that may distort effect sizes. They must also aim for minimum follow-up intervals of two years to confirm or refute potential gains of total hip arthroplasty over hemiarthroplasty in the fracture scenario.

It is noteworthy that, although derived from a small subset of studies, the findings of better hip function after total hip replacement were highly consistent. A reliable trade-off of the possible benefits and harms with total hip replacement also requires large scale data on health related quality of life.

\section{Other studies}

A recent meta-analysis of randomised trials identified three studies ${ }^{64}$ all included in this review. ${ }^{454650}$ The meta-analysis reported similar findings to this review, with higher reoperation rates and a trend for lower dislocation rates with hemiarthroplasty. Patients who had undergone total hip replacement were more likely to become mobile and less likely to require a second analgesic at 1, 2, 4, and 13 years, although this was not statistically significant at any assessment time. The greater proportion of mobile patients who had 


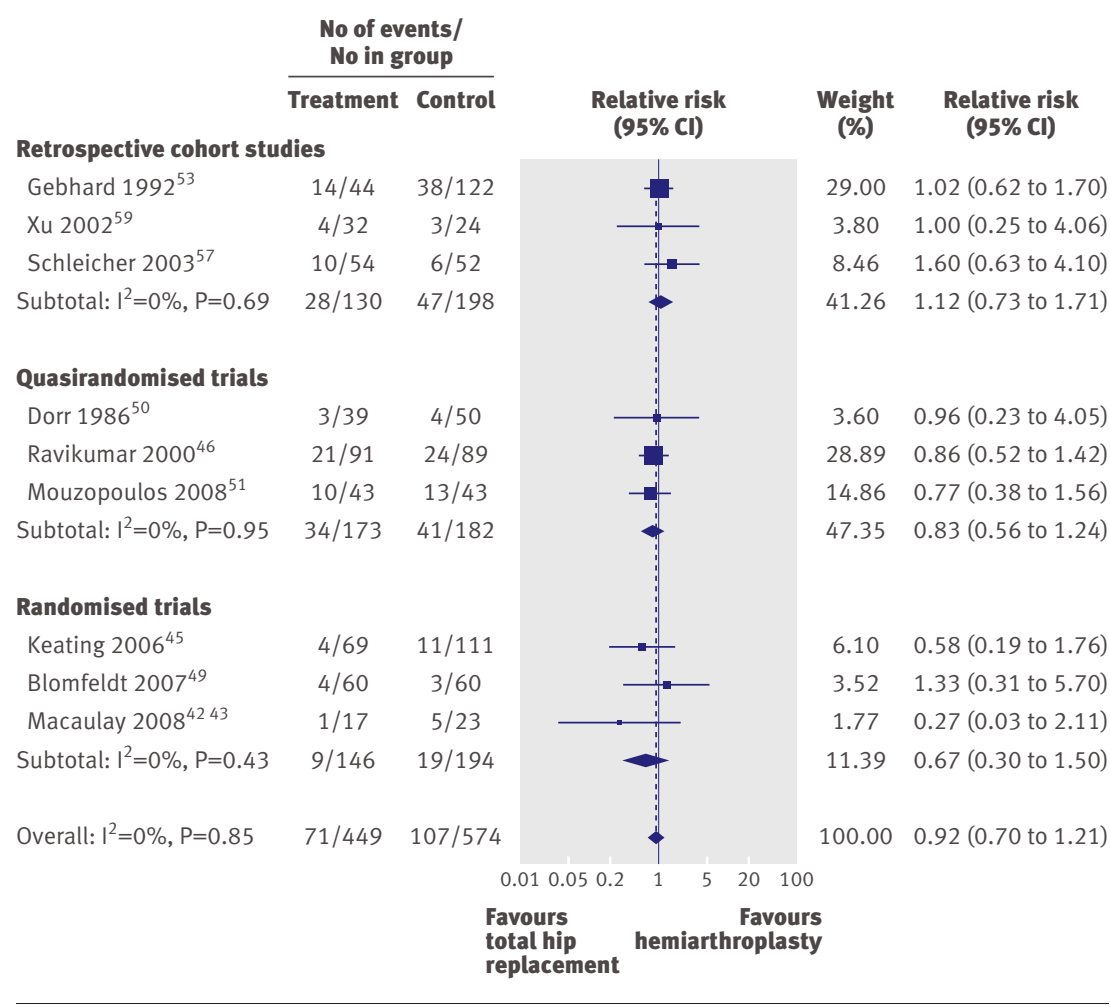

Fig 6 | Random effects meta-analysis comparing relative risk of one year mortality after total hip arthroplasty and hemiarthroplasty for displaced intracapsular hip fractures

undergone total hip replacement seems to correspond to the better hip function found with total hip replacement in this review. An earlier Cochrane review ${ }^{28}$ that compared cemented and cementless arthroplasty and internal fixation also carried out a meta-analysis of total hip arthroplasty compared with hemiarthroplasty based on three studies used in this review. ${ }^{454750}$ The Cochrane review found no significant differences between the interventions, although there was a trend for higher dislocation rates and lower reoperation rates with total hip replacement. Also, total hip arthroplasty was found to take about 20 minutes longer than hemiarthroplasty.

\section{Meaning of our review}

The optimal treatment strategy for hip fractures matters to healthcare professionals, policy makers, and payers of healthcare services, and should avoid costly reoperations, secondary hospital admissions, loss of independence, and physical disability. The noted $43 \%$ relative or $4 \%$ absolute reduction in the risk of reoperation with total hip arthroplasty is clinically important, given reported baseline risks of revision with hemiarthroplasty ranging from $6 \%$ to $18 \%{ }^{2123} \mathrm{It}$ must be kept in mind, however, that this is an aggregated effect mainly driven by data from trials with inadequate concealment. In contrast, total hip replacement was associated with a $48 \%$ relative or $1 \%$ absolute increase in the risk of dislocation. Avoiding further major surgical procedures is particularly relevant to patients with hip fractures, who are generally older and less healthy than the general population.
Considering the upper and lower confidence limits, it is possible that the reduction in the risk of reoperation may be smaller than the theoretical increase in the risk of dislocation. Under these circumstances, total hip replacement may still be the dominant treatment strategy, as dislocation can be managed on an outpatient basis and is a less serious event than reoperation. Also, the direct costs for a bipolar head in hemiarthroplasty may exceed those for a cemented polyethylene cup in total hip arthroplasty.

In this review, total hip replacement was not associated with a higher risk of deep infections, and a slightly higher risk of general complications did not result in higher mortality. Thus the procedure may be considered effective and safe in patients with intracapsular hip fractures, and a reasonable alternative to hemiarthroplasty.

We believe that the consistently better functional outcome ratings after total hip replacement are the most relevant findings of this review. However, the observed mean difference of 5.4 points in the total Harris hip score remains difficult to interpret, since no minimal important difference has currently been defined for this widely used outcome measure. The standardised mean difference derived from all five studies that had used at least one validated disease specific questionnaire was 0.42 , suggesting a medium treatment effect. ${ }^{63}$

\section{Unanswered questions and future research}

The results from this review cannot be considered conclusive owing to various interactions between strata. Furthermore, the improvement in function and health outcomes with total hip replacement was modest and only reported by a small number of studies. Therefore large scale clinical research to study the potential effects of total hip replacement on mobility and regain of independent living after displaced fractures of the femoral neck is merited. The quantitative findings from this review may allow for a better planning of those trials, selection of trial end points, and sample size estimation.

Patients are currently being recruited to the Hip Fracture Evaluation with Alternatives of Total Hip Arthroplasty versus Hemi-Arthroplasty trial, an initiative of the International Hip Fracture Research Collaborative. With a target sample size of 2500 patients for this study, the results from this trial, expected to be published in 2011, may allow for more conclusive inferences on this matter, but still must be interpreted in the light of current best evidence and the prior probability of effectiveness with either type of joint replacement. Additionally, a formal health economic analysis would be useful for providing greater clarity in decision making.

Patients with greater levels of activity treated with hemiarthroplasty may induce osteoarthritis more rapidly than in less active patients and, as they are likely to have a higher life expectancy, will be exposed to the risk of acetabular erosion for a longer period. Factors contributing to dislocation rates may be the 


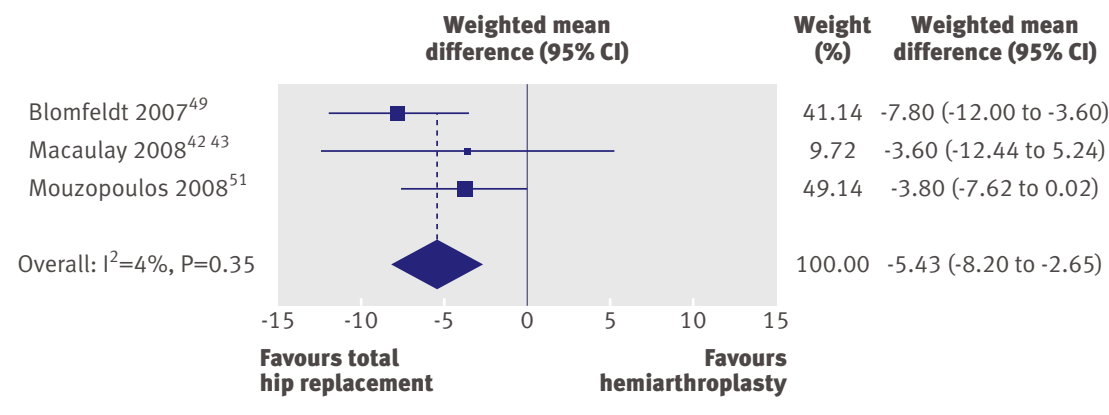

Fig 7| Random effects meta-analysis comparing weighted mean differences of Harris hip scores after total hip arthroplasty and hemiarthroplasty for displaced intracapsular hip fractures

surgical approach and the size of the prosthetic head. A multivariable analysis of dislocation after primary total hip replacement for all diagnoses found that a posterolateral approach and a smaller prosthetic head were associated with a higher rate of dislocation. ${ }^{65}$ Apart from choosing the optimal hardware, improving the surgical access route may help to reduce complications with this common procedure.

\section{Conclusion}

Although this review was limited to a small number of randomised controlled trials and retrospective cohort studies, some evidence suggested that patients treated with total hip arthroplasty for intracapsular hip fractures may have better outcomes than those treated with hemiarthroplasty.

The data currently available, however, do not yet allow for definitive conclusions about the scale and existence of some of the identified treatment effects, owing to varying interactions between subgroups, particularly those concerning random allocation of patients. Considering that a more frequent use of total hip replacement in oriented and mobile patients with displaced intracapsular hip fractures may be appropriate and save costs in the long run, an adequately powered trial is urgently needed to dispel these remaining doubts of the benefit to risk ratio with total hip replacement in the fracture setting.

\section{WHAT IS ALREADY KNOWN ON THIS TOPIC}

Arthroplasty is associated with lower reoperation rates and better function than internal fixation for patients with displaced intracapsular hip fractures

Total hip arthroplasty may be associated with better function than hemiarthroplasty in this setting and may also avoid secondary conversion surgery

A sample of randomised trials comparing both interventions was included in a recent systematic review, but an overview of the entire body of evidence is lacking

\section{WHAT THIS STUDY ADDS}

Data from 15 studies suggest that total hip arthroplasty is associated with lower reoperation rates and slightly better functional outcomes than hemiarthroplasty

Advantages with total hip arthroplasty must be traded off against a slightly higher risk of dislocations and general complications

Large well designed clinical trials comparing the two interventions are required before a definitive conclusion on their risk-benefit ratio can be reached
Contributors: $\mathrm{CH}$ conceived the study. $\mathrm{CH}$ and MW did the first data analyses, and DS did the final analyses. $\mathrm{CH}$ wrote the first draft of the protocol and the paper. $\mathrm{CH}, \mathrm{MW}$, and DS wrote the final draft of the paper and did the literature searches. All authors contributed to extracting and interpreting data and to revising the protocol and manuscript. CH and DS are the guarantors.

Funding All authors are independent of funders except $\mathrm{CH}$ who is an employee of DePuy International, a manufacturer of hip arthroplasty prostheses, which may have a financial interest in the results of this review.

Competing interests: All authors have completed the Unified Competing Interest form at www.icmje.org/coi_disclosure.pdf (available on request from the corresponding author) and declare that (1) $\mathrm{CH}$ has support from DePuy International a Johnson \& Johnson company for the submitted work; (2) DS, AE, and MW have no relationships with DePuy International a Johnson \& Johnson Company that might have an interest in the submitted work in the previous three years; (3) their spouses, partners, or children have no financial relationships that may be relevant to the submitted work; and (4) CH, DS, AE, and MW have no non-financial interests that may be relevant to the submitted work.

Ethical approval: Not required.

Data sharing: The technical appendix, and datasets extracted from individual papers and meta-analyses are available from the corresponding author at chopley@its.jnj.com.

1 Dorner T, Weichselbaum E, Lawrence K, Viktoria SK, Rieder A Austrian osteoporosis report: epidemiology, lifestyle factors, public health strategies. Wien Med Wochenschr 2009;159:221-9.

2 Nieves JW, Bilezikian JP, Lane JM, Einhorn TA, Wang Y, Steinbuch M, et al. Fragility fractures of the hip and femur: incidence and patient characteristics. Osteoporos Int 2010;21:399-408.

3 Eklund F, Nordstrom A, Neovius M, Svensson O, Nordstrom P. Variation in fracture rates by country may not be explained by differences in bone mass. Calcif Tissue Int 2009;85:10-6.

4 Abrahamsen B, Vestergaard P. Declining incidence of hip fractures and the extent of use of anti-osteoporotic therapy in Denmark 1997 2006. Osteoporos Int 2010;21:373-80.

5 Sirois MJ, Cote M, Pelet S. The burden of hospitalized hip fractures: patterns of admissions in a level I trauma center over 20 years. Trauma 2009;66:1402-10.

6 Holt G, Smith R, Duncan K, Hutchison JD, Reid D. Changes in population demographics and the future incidence of hip fracture. Injury 2009;40:722-6.

7 Icks A, Haastert B, Wildner M, Becker C, Rapp K, Dragano N, et al. Hip fractures and area level socioeconomic conditions: a populationbased study. BMC Public Health 2009;9:114

8 Dodds MK, Codd MB, Looney A, Mulhall KJ. Incidence of hip fracture in the Republic of Ireland and future projections: a population-based study. Osteoporos Int 2009:20:2105-10.

9 Tsang SW, Kung AW, Kanis JA, Johansson H, Oden A. Ten-year fracture probability in Hong Kong southern Chinese according to age and BMD femoral neck T-scores. Osteoporos Int 2009;20:1939-45.

10 Fisher AA, O’Brien ED, Davis MW. Trends in hip fracture epidemiology in Australia: possible impact of bisphosphonates and hormone replacement therapy. Bone 2009;45:246-53.

11 Oliver D, Connelly JB, Victor CR, Shaw FE, Whitehead A, Genc Y, et al. Strategies to prevent falls and fractures in hospitals and care homes and effect of cognitive impairment: systematic review and metaanalyses. BMJ 2007:334:82-5.

12 Bischoff-Ferrari HA, Willett WC, Wong JB, Giovannucci E, Dietrich T, Dawson-Hughes B. Fracture prevention with vitamin D supplementation: a meta-analysis of randomized controlled trials. IAMA 2005:293:2257-64.

13 Bischoff-Ferrari HA, Dawson-Hughes B, Willett WC, Staehelin HB, Bazemore MG, Zee RY, et al. Effect of Vitamin D on falls: a metaanalysis. JAMA 2004:291:1999-2006.

14 Iwamoto J, Sato Y, Takeda T, Matsumoto H. Hip fracture protection by alendronate treatment in postmenopausal women with osteoporosis: a review of the literature. Clin Interv Aging 2008:3:483-9.

15 Wells G, Cranney A, Peterson J, Boucher M, Shea B, Robinson V, et al. Risedronate for the primary and secondary prevention of osteoporotic fractures in postmenopausal women. Cochrane Database Syst Rev 2008;1:CD004523.

16 Wells GA, Cranney A, Peterson J, Boucher M, Shea B, Robinson V, et al. Etidronate for the primary and secondary prevention of osteoporotic fractures in postmenopausal women. Cochrane Database Syst Rev 2008;1:CD003376.

17 Reid IR, Bolland MJ, Grey A. Effect of calcium supplementation on hip fractures. Osteoporos Int 2008:19:1119-23.

18 MacLean C, Newberry S, Maglione M, McMahon M, Ranganath V, Suttorp M, et al. Systematic review: comparative effectiveness of 
treatments to prevent fractures in men and women with low bone density or osteoporosis. Ann Intern Med 2008;148:197-213.

19 Jackson C, Gaugris S, Sen SS, Hosking D. The effect of cholecalcifero (vitamin D3) on the risk of fall and fracture: a meta-analysis. $Q J \mathrm{Med}$ 2007;100:185-92.

20 Sahni S, Hannan MT, Gagnon D, Blumberg J, Cupples LA, Kiel DP, et al. Protective effect of total and supplemental vitamin $C$ intake on the risk of hip fracture-a 17-year follow-up from the Framingham Osteoporosis Study. Osteoporos Int 2009;20:1853-61.

21 Rogmark C, Johnell O. Primary arthroplasty is better than internal fixation of displaced femoral neck fractures: a meta-analysis of 14 randomized studies with 2,289 patients. Acta Orthop 2006;77:359-67.

22 Frihagen F, Nordsletten L, Madsen JE. Hemiarthroplasty or internal fixation for intracapsular displaced femoral neck fractures: randomised controlled trial. BMJ 2007;335:1251-4.

23 Bhandari M, Devereaux PJ, Swiontkowski MF, Tornetta P III, Obremskey W, Koval KJ, et al. Internal fixation compared with arthroplasty for displaced fractures of the femoral neck: a metaanalysis. J Bone Joint Surg Am 2003;85-A:1673-81.

24 Scottish Intercollegiate Guidelines Network. Management of hip fracture in older people: a national clinical guideline. Scottish Intercollegiate Guidelines Network, 2009.

25 Kakar S, Tornetta P III, Schemitsch EH, Swiontkowski MF, Koval K, Hanson BP, et al. Technical considerations in the operative management of femoral neck fractures in elderly patients: a multinational survey. J Trauma 2007;63:641-6.

26 Bhandari M, Devereaux PJ, Tornetta P III, Swiontkowski MF, Berry DJ, Haidukewych G, et al. Operative management of displaced femoral neck fractures in elderly patients: an international survey. J Bone Join Surg Am 2005;87:2122-30.

27 Sayana MK, Lakshmanan P, Peehal JP, Wynn-Jones C, Maffulli N. Total hip replacement for acute femoral neck fracture: a survey of National Joint Registries. Acta Orthop Belg 2008;74:54-8.

28 Parker MJ, Gurusamy K. Arthroplasties (with and without bone cement) for proximal femoral fractures in adults. Cochrane Database Syst Rev 2006;3:CD001706.

29 Parker MJ, Handoll HH. Replacement arthroplasty versus internal fixation for extracapsular hip fractures in adults. Cochrane Database Syst Rev 2006;2:CD000086.

30 Dawson J, Fitzpatrick R, Frost S, Gundle R, McLardy-Smith P, Murray D. Evidence for the validity of a patient-based instrument for assessment of outcome after revision hip replacement. J Bone Joint Surg Br 2001;83:1125-9.

31 DerSimonian R, Laird N. Meta-analysis in clinical trials. Control Clin Trials 1986;7:177-88.

32 Higgins JP, Thompson SG, Deeks JJ, Altman DG. Measuring inconsistency in meta-analyses. BMJ 2003;327:557-60.

33 Egger M, Davey SG, Schneider M, Minder C. Bias in meta-analysis detected by a simple, graphical test. BMJ 1997;315:629-34.

34 Altman DG, Bland JM. Interaction revisited: the difference between two estimates. BMJ 2003;326:219.

35 Harris RJ, Bradburn MJ, Deeks JJ, Harbord RM, Altman DG, Sterne JAC. Metan: fixed- and random-effects meta-analysis. Stata J 2008;8:3-28.

36 Geiger F, Schreiner K, Schneider S, Pauschert R, Thomsen M. [Proximal fracture of the femur in elderly patients. The influence of surgical care and patient characteristics on post-operative mortality.] Orthopade 2006;35:651-7.

37 Geiger F, Zimmermann-Stenzel M, Heisel C, Lehner B, Daecke W. Trochanteric fractures in the elderly: the influence of primary hip arthroplasty on 1-year mortality. Arch Orthop Trauma Surg 2007;127:959-66.

38 Haentjens P, Casteleyn PP, Opdecam P. Primary bipolar arthroplasty or total hip arthroplasty for the treatment of unstable intertrochanteric and subtrochanteric fractures in elderly patients. Acta Orthop Belg 1994;60(suppl 1):124-8S.

39 Dzupa V, Bartonicek J, Skala-Rosenbaum J, Prikazsky V. [Mortality in patients with proximal femoral fractures during the first year after the injury.] Acta Chir Orthop Traumatol Cech 2002;69:39-44.

40 Hussain A, Prasad KS. Mortality among elderly patients with fracture of the hip. JK Pract 2003;10:4-9.

41 Broos PL, Stappaerts KH, Luiten EJ, Gruwez JA. Endoprosthesis: the best way to treat unstable intracapsular hip fractures in elderly patients. Unfallchirurg 1987;90:347-50.

42 Macaulay W, Nellans KW, lorio R, Garvin KL, Healy WL, Rosenwasser MP. Total hip arthroplasty is less painful at 12 months compared with hemiarthroplasty in treatment of displaced femoral neck fracture. HSS J 2008;4:48-54.

43 Macaulay W, Nellans KW, Garvin KL, Iorio R, Healy WL, Rosenwasser MP. Prospective randomized clinical trial comparing hemiarthroplasty to total hip arthroplasty in the treatment of displaced femoral neck fractures: winner of the Dorr award. $J$ Arthroplasty 2008;23:2-8.

44 Keating JF, Grant A, Masson M, Scott NW, Forbes JF. Displaced intracapsular hip fractures in fit, older people: a randomised comparison of reduction and fixation, bipolar hemiarthroplasty and total hip arthroplasty. Health Technol Assess 2005;9:iii-x, 1.

45 Keating JF, Grant A, Masson M, Scott NW, Forbes JF. Randomized comparison of reduction and fixation, bipolar hemiarthroplasty, and total hip arthroplasty. Treatment of displaced intracapsular hip fractures in healthy older patients. J Bone Joint Surg Am 2006;88:249-60.

46 Ravikumar KJ, Marsh G. Internal fixation versus hemiarthroplasty versus total hip arthroplasty for displaced subcapital fractures of femur-13 year results of a prospective randomised study. Injury 2000;31:793-7.

47 Skinner P, Riley D, Ellery J, Beaumont A, Coumine R, Shafighian B. Displaced subcapital fractures of the femur: a prospective randomized comparison of internal fixation, hemiarthroplasty and total hip replacement. Injury 1989;20:291-3.

48 Baker RP, Squires B, Gargan MF, Bannister GC. Total hip arthroplasty and hemiarthroplasty in mobile, independent patients with a displaced intracapsular fracture of the femoral neck: a randomized, controlled trial. J Bone Joint Surg Am 2006;88:2583-9.

49 Blomfeldt R, Tornkvist H, Eriksson K, Soderqvist A, Ponzer S, Tidermark J. A randomised controlled trial comparing bipola hemiarthroplasty with total hip replacement for displaced intracapsular fractures of the femoral neck in elderly patients. J Bone Joint Surg Br 2007;89:160-5.

50 Dorr LD, Glousman R, Hoy AL, Vanis R, Chandler R. Treatment of femoral neck fractures with total hip replacement versus cemented and noncemented hemiarthroplasty. J Arthroplasty 1986;1:21-8.

51 Mouzopoulos G, Stamatakos M, Arabatzi H, Vasiliadis G, Batanis G, Tsembeli A, et al. The four-year functional result after a displaced subcapital hip fracture treated with three different surgical options. Int Orthop 2008;32:367-73.

52 Eyssel M, Schwenk W, Badke A, Krebs S, Stock W. [Total endoprosthesis or dual head prosthesis in endoprosthetic management of femoral neck fractures?] Unfallchirurg 1994; $97: 347-52$.

53 Gebhard JS, Amstutz HC, Zinar DM, Dorey FJ. A comparison of total hip arthroplasty and hemiarthroplasty for treatment of acute fracture of the femoral neck. Clin Orthop Relat Res 1992;123-31.

54 Healy WL, Iorio R. Total hip arthroplasty: optimal treatment for displaced femoral neck fractures in elderly patients. Clin Orthop Relat Res 2004;43-8.

55 Levi N. Early mortality after cervical hip fractures. Injury 1996;27:565-7.

56 Narayan KK, George T. Functional outcome of fracture neck of femur treated with total hip replacement versus bipolar arthroplasty in a South Asian population. Arch Orthop Trauma Surg 2006;126:545-8.

57 Schleicher I, Kordelle J, Jurgensen I, Haas H, Melzer C. [Femoral neck fractures in the elderly-bipolar hemiarthroplasty in total hip replacement.] Unfallchirurg 2003;106:467-71.

58 Squires B, Bannister G. Displaced intracapsular neck of femur fractures in mobile independent patients: total hip replacement or hemiarthroplasty? Injury 1999;30:345-8.

59 Xu X, Liu Y, Liu J, Li Y. Prosthetic replacement in treatment of subcapital femoral neck fractures in the elderly. Chin J Traumatol 2002;5:28-31.

60 Harris WH. Traumatic arthritis of the hip after dislocation and acetabular fractures: treatment by mold arthroplasty. An end-result study using a new method of result evaluation. J Bone Joint Surg Am 1969;51:737-55.

61 Johanson NA, Charlson ME, Szatrowski TP, Ranawat CS. A selfadministered hip-rating questionnaire for the assessment of outcome after total hip replacement. J Bone Joint Surg Am 1992;74:587-97.

62 Dawson J, Fitzpatrick R, Murray D, Carr A. Comparison of measures to assess outcomes in total hip replacement surgery. Qual Health Care 1996;5:81-8.

63 Hasselblad V, Hedges LV. Meta-analysis of screening and diagnostic tests. Psychol Bull 1995;117:167-78.

64 Goh SK, Samuel M, Su DH, Chan ES, Yeo SJ. Meta-analysis comparing total hip arthroplasty with hemiarthroplasty in the treatment of displaced neck of femur fracture. J Arthroplasty 2009;24:400-6.

65 Berry DJ, von Knoch M, Schleck CD, Harmsen WS. Effect of femoral head diameter and operative approach on risk of dislocation after primary total hip arthroplasty. J Bone Joint Surg Am 2005;87:2456-63.

Accepted: 12 April 2010 